Stratigraphy of the

Washakie Formation in the

Washakie Basin,

Wyoming

G E O LOG I CAL S UR VEY B ULLE TIN 1369

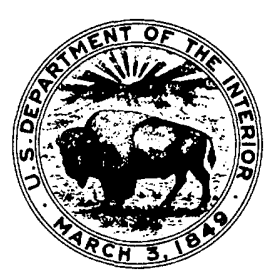




\section{Stratigraphy of the}

\section{Washakie Formation in the}

\section{Washakie Basin,}

\section{Wyoming}

By HENRY W. ROEHLER

G E O L O G I A L S U R V E Y B U L L E T I N 1369

The name Washakie Formation is revived for Eocene fluvial rocks that overlie the Green River Formation in the

Washakie Basin. The formation is then divided into the Kinney Rim and Adobe Town Members

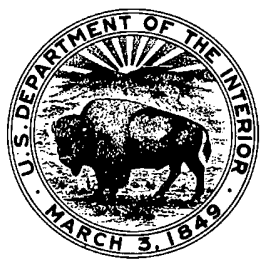




\section{UNITED STATES DEPARTMENT OF THE INTERIOR \\ ROGERS C. B. MORTON, Secretary}

\section{GEOLOGICAL SURVEY}

V. E. McKelvey, Director

Library of Congress catalog-card No. 72-600329

For sale by the Superintendent of Documents, U. S. Government Printing Office Washington, D. C. 20402

Stock No. 2401-00286 


\section{CONTENTS}

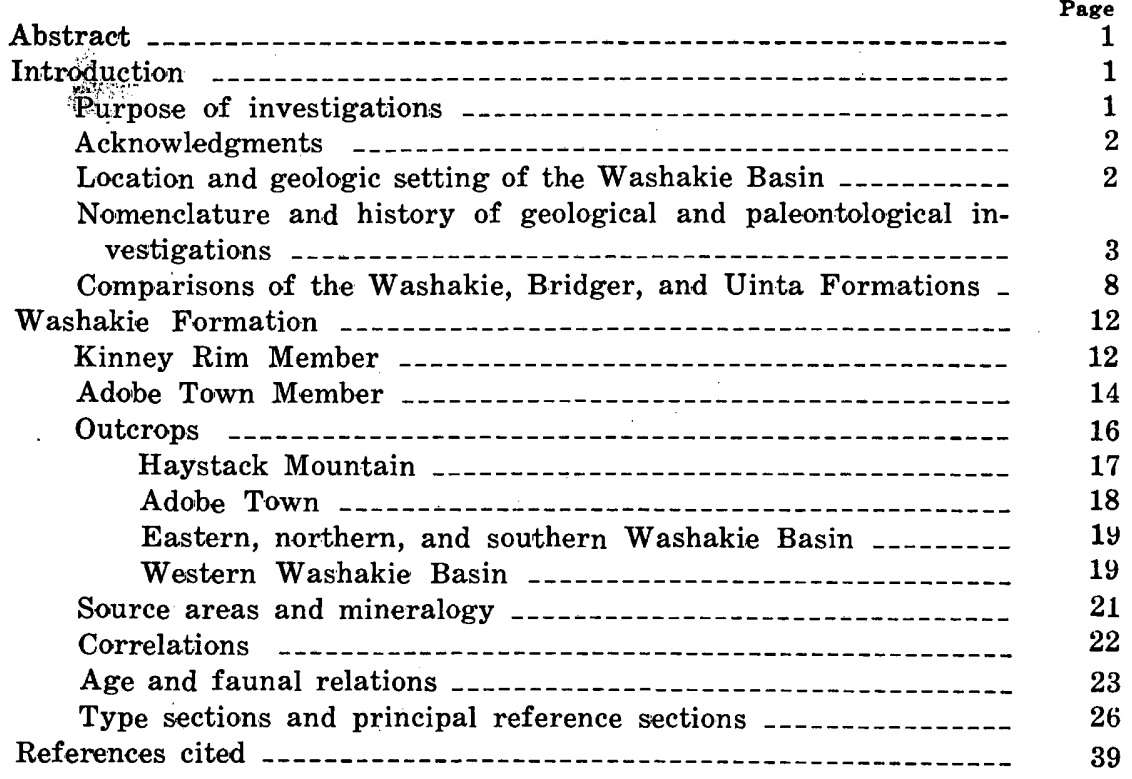

\section{ILLUSTRATIONS}

Plate 1. West-east stratigraphic section and electric log cross Page section of the Washakie Formation and adjacent parts of the Laney Shale Member of the Green River Formation and Cathedral Bluffs Tongue of the Wasatch Formation in the Washakie Basin, Wyoming -...-..... In pocket

2. Graphic sections of the Washakie Formation in the

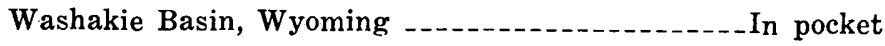

FIGURE 1. Map showing the major physiographic features of the Washakie Basin 
FiguRE 2. Correlation chart of the Green River, Washakie, and Uinta Formations

Page

3-10. Photographs of :

3. The white ridge marker bed (bed 515) on the east slopes of Kinney Rim -...

4. The robin's-egg-blue marker bed (bed 579) --

5. Outcrops of the Adobe Town Member at the east edge of Haystack Mountain

6. Outcrops of the Adobe Town Member at Adobe Town

7. Outcrops of the lower brown sandstones in

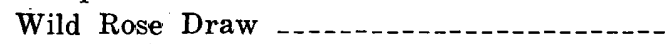

8. The sandstone rim below the Adobe Town Rim The arkosic sandstones of the Adobe Town Member that cap Haystack Mountain -.....-.-

10. Desert pavement in the western part of the

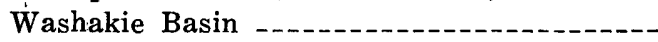

\section{TABLES}

TABLE 1. Lithologic differences between the Kinney Rim and Adobe Town Members of the Washakie Formation --

2. Vertebrate localities and partial list of fauna in the Washakie Formation 


\title{
STRATIGRAPHY OF THE WASHAKIE FORMATION IN THE WASHAKIE BASIN, WYOMING
}

\author{
By Henry W. Roehler
}

\begin{abstract}
Since 1869 fluvial rocks of middle and late Eocene age in the Washakie Basin in southwest Wyoming have been variously assigned to the Bridger Formation, the undivided Bridger and Uinta Formations, or the Washakie Formation. In this report the name Washakie Formation is reintroduced for use in the Washakie Basin, and the names Bridger Formation and Uinta Formation are dropped in that basin.

The Washakie Formation is a thick sequence of interbedded tuffaceous and arkosic sandstone; gray, green, or red mudstone; and minor thin beds of tuff, limestone, conglomerate, shale, and siltstone. The beds are numbered, described, and assigned to newly named members for which type sections and principal reference sections are designated, and key reference horizons are shown in correlation diagrams. The lower $900 \pm$ feet of the formation is named the Kinney Rim Member; the upper 2,300 \pm feet of the formation is named the Adobe Town Member. The two members are separated by an unconformity, and are distinguished by minor lithologic differences. The Kinney Rim Member is missing in the eastern part of the basin, partly by erosion and truncation and partly by complex intertonguing and lateral replacement by the Laney Shale Member of the Green River Formation. The members are exposed in badlands between major sandstone ridges that slope basinward toward the central-southwestern part, or structural center, of the Washakie Basin. The Adobe Town Member comprises the youngest Tertiary strata across the center of the basin.

Vertebrate fossils are widely distributed, and they indicate a middle Eocene (Bridger A-B and Bridger C-D) age for the Kinney Rim Member and a middle Eocene (Bridger C-D) and late Eocene (Uinta B) age for the Adobe Town Member. The age and stratigraphic relations of the Bridger, Washakie, and Uinta Formations are briefly reviewed.
\end{abstract}

\section{INTRODUCTION}

\section{PURPOSE OF INVESTIGATIONS}

Geologic mapping and stratigraphic studies by the U.S. Geological Survey to locate and evaluate oil-shale deposits in the intermontane Tertiary basins of the Central Rocky Mountains 
have included investigation of Eocene rocks in the Washakie Basin in southwest Wyoming where thick oil-shale deposits are known. In 1968 a field reconnaissance was made in this poorly explored desert basin, numerous stratigraphic sections were measured, and a geologic map was prepared at the scale of $1: 125,000$ on a planimetric base. From this reconnaissance work, a stratigraphic framework of key beds and unit contracts was developed for the geologic mapping of nearly fifty $71 / 2$-minute quadrangles that cover the Washakie Basin. The purpose of this paper is to describe briefly the fluvial rocks of middle and late Eocene age that overlie the Green River Formation in the remote central part of the basin, to define the major stratigraphic units, and to review information bearing on their ages. Certain changes and refinements in the stratigraphic nomenclature are also proposed. The name Washakie Formation is revived for rocks formerly assigned to the undivided Bridger and Uinta Formations, or the Bridger Formation, and the names Kinney Rim and Adobe Town are proposed as members of the Washakie Formation.

\section{ACKNOWLEDGMENTS}

I thank C. L. Gazin, of the National Museum of Natural History, and P. O. McGrew, of the University of Wyoming, for identifying vertebrate fossils and establishing their ages. The generous aid of W. D. Turnbull, of the Field Museum of Natural History, who has accompanied me on numerous long field trips through the basin to establish stratigraphic correlations, and who has allowed the publication herein of new faunal data from his recent collections, is appreciatively acknowledged. W. J. Mapel, G. E. Lewis, W. C. Culbertson, W. D. Turnbull, P. O. McGrew, J. D. Love, and D. N. Miller, Jr., read the manuscript and suggested changes.

\section{LOCATION AND GEOLOGIC SETTING OF THE WASHAKIE BASIN}

The Washakie Basin is a structural and topographic basin which consists of an area of about 2,500 square miles north of the Colorado-Wyoming State line in southwest Wyoming (fig. 1). The basin is bounded by the major structural features, the Sierra Madre and the Rock Springs uplift to the east and west respectively, and by the minor anticlinal folds, the Wamsutter Arch and the Cherokee Ridge to the north and south respectively. The overall configuration of the basin is that of a very broad, roughly square bowl having an encircling rim formed by the Laney Shale Member of the Green River Formation. Along its western part the rim is known as Kinney Rim, and in its northern part it is 
known as Laney Rim. The asymmetrical shape of the basin results from the presence of several anticlinal noses that plunge basinward from the basin margins. The major synclinal axis is oriented in a northeast direction, slightly west of the geographic center of the basin. Lacustrine and fluvial Eocene rocks nearly 8,000 feet thick are exposed in badlands and ridges across the basin, except in small areas where the later Tertiary Bishop Conglomerate and Browns Park Formation cap high ridges, and where Quaternary alluvium and sand dunes fill intermittent stream valleys and cover areas of low relief. Major topographic features formed by outcrops of the Washakie Formation, such as Adobe Town and Haystack Mountain, are discussed in detail later in this report.

Altitudes above sea level range from 8,700 feet at Pine Butte in the western part of the basin to 6,100 feet in drainages in the southeastern part of the basin, and they average about 6,700 feet. Rainfall is less than 10 inches per year, which supports only sparse vegetation consisting mostly of sagebrush, greasewood, and desert grasses. No perennial streams cross the basin, but in a few places springs provide water and sufficient grass for grazing cattle and sheep. Except for a few herders, the basin is uninhabited.

\section{NOMENCLATURE AND HISTORY OF GEOLOGICAL AND PALENTOLOGICAL INVESTIGATIONS}

The name Washakie Group was applied by Hayden (1869, p. 190) to exposures near Washakie Station (now Wamsutter, Wyo.) between Creston Station and Bitter Creek Station on the Union Pacific Railroad, which parallels the north edge of the Washakie Basin. Hayden never specifically designated the contacts of the Washakie Group, but the section between Creston and Bitter Creek includes the lower Eocene parts of what are now called the Wasatch and Green River Formations. His reference to "impure lignite, with vast quantities of fossils belonging to the genera Unio, Melania, Vivipara, Helix, etc." is suggestive of rocks which are exposed along the railroad and which characterize the Luman Tongue of the Green River Formation and the Niland Tongue of the Wasatch Formation of the present-day nomenclature. In his record of a trip through the Washakie Basin on the Overland Trail in 1870, Hayden (1871, p. 71) wrote that "soon after leaving Black Buttes we cross the western rim of the series of middle tertiary beds, which I have named the 'Washakie group'." The fact that the coal-bearing Fort Union Formation of Paleocene age is exposed for several miles east of 


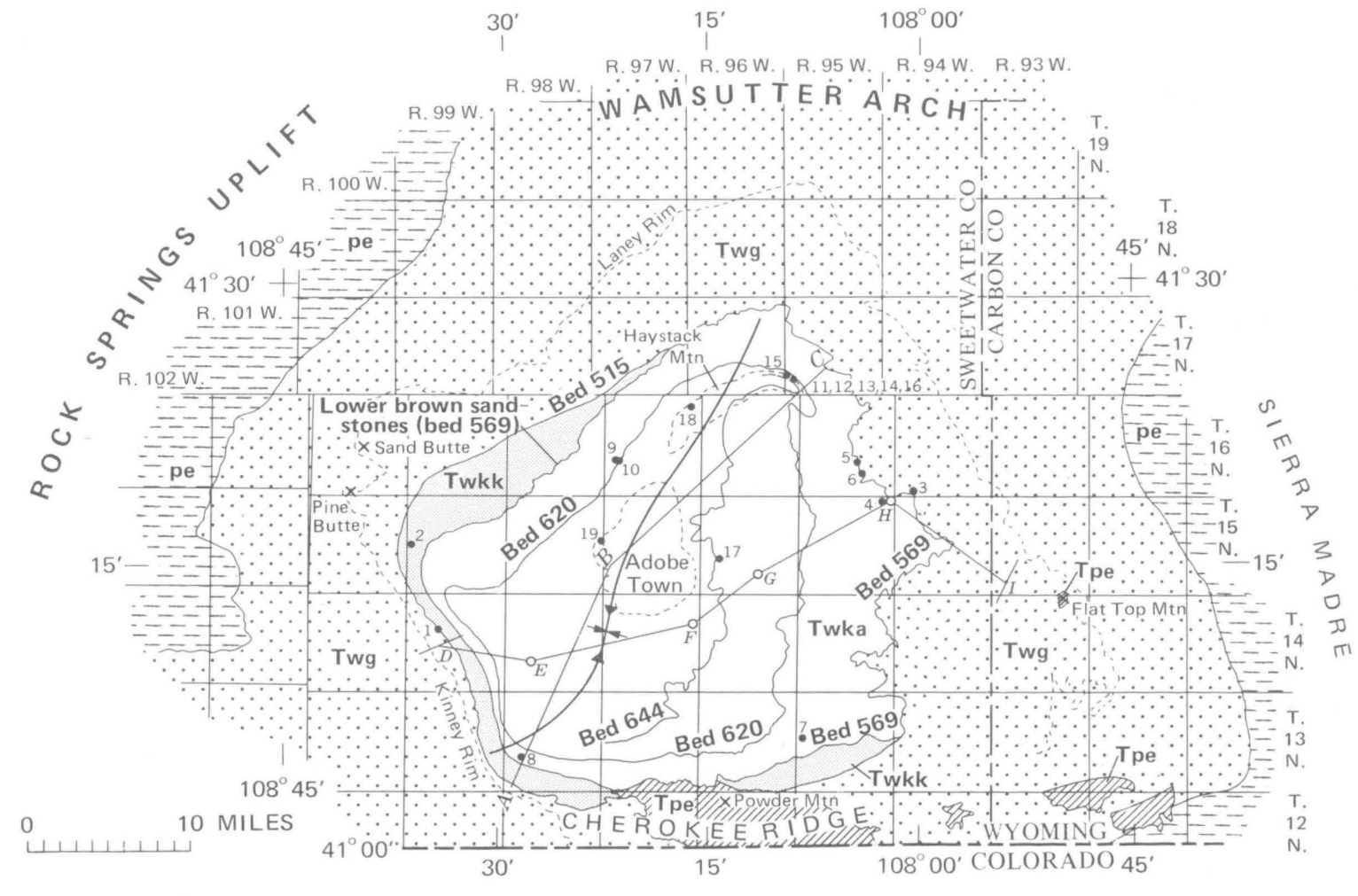

年 


\section{EXPLANATION}

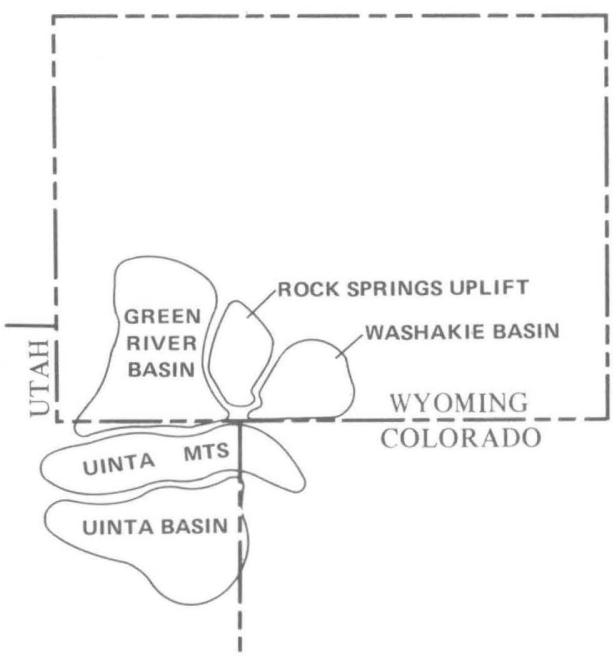

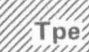

Post-Eocene Tertiary formations

\begin{tabular}{|c|}
\hline Twka \\
\hline Twkk \\
\hline
\end{tabular}

Eocene Washakie Formation

Twka, Adobe Town Member

Twkk, Kinney Rim Member

$$
\because \text { Twg }
$$

Eocene Wasatch and Green River Formations

$$
\begin{array}{r}
-1=-1 \\
-\mathbf{p e}=-1
\end{array}
$$

Pre-Eocene rocks
Major topographic feature or outline of a topographic feature

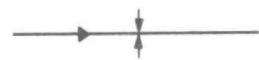

Axis of syncline, showing plunge

Well location

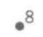

Fossil-mammal locality

FIGURE 1.-The major physiographic features of the Washakie Basin. Generalized geology includes the area underlain by the Washakie Formation; the locations of key beds in the Washakie Formation; the approximate locations of the graphic section, $A, B$, and $C$; the location of a west-east stratigraphic and electric log section, $D$, $E, F, G, H$, and $I$; and the fossil mammal localities. 
Black Butte Station in the direction he was traveling leads one to believe that he may also have included the Fort Union Formation there in the Washakie Group. A few years later, Hayden (1877, p. 181-185) published notes on artesian borings along the Union Pacific Railroad between Rawlins, Wyo., and Point of Rocks, Wyo. At that time Hayden realized that his Washakie Group was the stratigraphic equivalent of the Wasatch Group. By acknowledging the priority of the name Wasatch Group, he effectively abandoned the name Washakie Group. Hence the name Washakie Group as applied to lower Eocene rocks was never formalized and it was not used after the year 1877 .

The physiography of the Washakie Basin was described by King in 1877 (p. 211-222). Many of the names of topographic features and landmarks have changed since King's explorations, but his descriptions are nevertheless accurate and detailed. King assigned the beds occupying the center of the Washakie Basin, above the "Green River group," to the Bridger series," and correlated them with the "Bridger group" of Hayden (1869, p. 191 ) in southwestern Wyoming. In locating Bridger outcrops, King made two important observations that were missed by many later geologists: (1) The beds composing the top of Haystack Mountain are not the uppermost Bridger (Washakie) strata in the basin; and (2) Bridger (Washakie) beds are present in the east slopes of Kinney Rim. King (1876) published the earliest geologic map that includes the Washakie Basin. King $(1878$, p. 447-448) proposed the name "Washakie Lake" for the basin wherein all of the Bridger beds were deposited in southwest Wyoming, but the term Washakie Lake is now obsolete. Research of the literature suggests that King may have been the first to use the names "Washakie Basin," "Cathedral Bluffs," "Pine Bluffs," and "Haystack Mountain."

Early stratigraphic and paleontologic investigations of King's (1877) "Bridger series" were undertaken by Osborn and McMaster, who were companions on a field party from Princeton College that explored the Washakie Basin in 1878. Osborn (1881, p. 9-15) summarized the topography, age, stratigraphy, and depositional history of the post-Green River rocks as well as the paleontology. Although it was not his stated intention to introduce a new stratigraphic term, Osborn at times referred to the "Bridger series" in the Washakie Basin as the "Washakie beds," "Washakie Basin beds," and "Washakie basin strata." McMaster (1881, p. 51-54) measured sections on the north and south slopes of Haystack Mountain (fig. 1), where 29 beds make up a composite section about 700 feet thick, and he published lithologic 
descriptions of these rocks. Years later, Granger (1909, p. 15) reported an error in the joining of two of McMaster's sections; this error becomes important in interpreting the early work.

Granger (1909, p. 13) stated that the name "Washakie formation" was used by W. J. Sinclair in a paper entitled "The Washakie, A Volcanic Ash Formation" presented orally before the American Society of Vertebrate Paleontologists at New Haven in December 1907. In a published paper under the same title, Sinclair $(1909$, p. 25) concluded that there was ample petrographic and faunal evidence for separating the Washakie from the Bridger Formation in southwestern Wyoming. The petrographic evidence for the separation was later refuted by W. D. Matthew (in Johannsen, 1914, p. 210) following additional work by Johannsen.

Detailed stratigraphy and paleontology of the Washakie Formation was reported by Granger (1909, p. 19-20), who measured a section on the east slopes of Haystack Mountain and described 22 beds that were 642 feet thick. I measured the same section and found it to have a thickness of 1,330 feet. [A discrepancy in Granger's measurements was also noted by Wheeler (1961, p. 14), who reported 1,160 feet in a similar stratigraphic section.] Granger divided the Washakie Formation at Haystack Mountain into Washakie A, or lower Washakie Formation, and Washakie B, or upper Washakie Formation. He also established faunal zones within the formation and compared the mammal genera of the Washakie Formation with that of the Bridger and Uinta Formations.

Schultz (1920, pl. 1), in conjunction with a study of oil possibilities in and around the Baxter Basin, mapped the Washakie Basin, Rock Springs uplift, and part of the Green River Basin at a scale of $1: 250,000$. He included in the Bridger Formation the beds from both the Washakie Basin and the Bridger Basin.

Osborn reexplored most of the rocks of Eocene age in the Western United States. He presented (1929 p. 90) a revised columnar section of the Washakie Formation at Haystack Mountain, showing life zones that were based on the stratigraphic work of Granger.

Bradley $(1945,1964)$ compiled two geologic maps of the Washakie Basin and adjacent areas, on which he used Schultz's (1920) nomenclature with some modifications. Bradley's 1945 map, at a scale of about $1: 200,000$, showed a "conformable" contact between the Bridger and Green River Formations; and he explained that the boundary of these units "probably is not drawn consistently on the same stratigraphic horizon." On his 1964 map 
(Bradley, pl. 1), at the scale of $1: 250,000$, he modified the contact of the Bridger and Green River Formations from that shown on the 1945 map, but he still showed it as conformable in most places. Bradley ( 1964, p. A54) stated that the contact shown on the later map was located on aerial photographs in the field along the east slopes of Kinney Rim and subsequently was traced all around the Washakie Basin photogrammetrically. The revised contact on the 1964 map is near the "lower brown sandstones" of the present report (bed $569^{1}$, fig. 1). The name Uinta Formation was introduced and applied to the uppermost Bridger beds (Washakie B of Granger, 1909) in the Washakie Basin by Bradley $(1964$, p. A54), because of similar "age relations" to the Uinta Formation. Although the Uinta Formation was not mapped separately, Bradley stated that "the thickest section of the Bridger and Uinta Formations in the Washakie Basin is exposed on the flanks of Haystack Mountain (T. 16 N., R. 95 W.) $* * *$ there the basal 50-75 feet of the Bridger is not well exposed, but above that about 780 feet of the two formations is perfectly exposed."

Morris (1954, p. 195-203) studied an Eocene fauna from the Cathedral Bluffs Tongue of the Wasatch Formation in the Washakie Basin. He reverted to the name Washakie Formation for the middle and upper Eocene fluvial rocks overlying the Green River Formation.

In a paper that revised the taxonomy of the uintatheres, Wheeler (1961, p. 15) wrote, "a question still remains as to whether the post-Green River Eocene deposits of the Washakie Basin should be called Washakie formation or Bridger formation," but he concluded that "because the post-Green River Eocene strata are geographically and lithologically distinct from both the Bridger and Uinta formations, and because Bridger and Uinta are chronostratigraphic as well as lithostratigraphic names, and because there are both Bridgerian and Uintan elements in the faunas, it is best to refer these beds to a separate formation, the Washakie."

I agree with the conclusions of Wheeler (1961) and others that the post-Green River Eocene beds in the Washakie Basin should be distinguished from the Bridger and Uinta Formations. The name Washakie Formation is selected in preference to a new name, because it is entrenched in the literature and is widely used.

\section{COMPARISONS OF THE WASHAKIE, BRIDGER, AND UINTA FORMATIONS}

The Washakie, Bridger, and Uinta Formations generally re-

\footnotetext{
1 The numbered beds referred to in this report are described in stratigraphic sections at the end of this report. The localities of some of these beds are shown in figure 1 .
} 
semble each other in that they are partly time-equivalent fluvial rocks largely composed of air-laid volcanic ash that overlie the lacustrine Green River Formation (fig. 2). However, the three formations differ from each other in five important ways:

1. They crop out in different basins that are separated by the Uinta Mountains or the Rock Springs uplift. There is no evidence to suggest that the Washakie and the Uinta Formations were connected across the Uinta Mountains at any time during their depositional histories. The closest outcrops of the Washakie and the Bridger Formations, on the east and west flanks of the Rock Springs uplift, are about 50 miles apart. The Washakie Formation may be an eastward extension of the Bridger Formation, but the evidence for this connection was removed by middle-late Tertiary erosion across the crest of the Rock Springs uplift. King (1877, p. 204, 218) and Osborn (1881, p. 12-13) cited significant reasons for believing that the Washakie and Bridger Basins were not continuous.

2. The lithology of the Washakie Formation is different from that of the Bridger and Uinta Formations in both color and mineral composition. Weathered outcrops of the Washakie Formation are variously pastel shades of gray, green, tan, or red; those of the Bridger Formation are mostly darker shades of gray or green. The Uinta Formation has two distinctive color facies-tan brown to green and red to red brown. All three formations probably had a common source for the volcanic sediments that make up so much of the rocks, but they had local independent source areas for most of the clastic rocks. For example, as much as 60 percent of the strata in parts of the Washakie Formation is composed of arkose derived from the plutonic core of the Sierra Madre east of the Washakie Basin. Arkose is generally a minor constituent of the rocks that compose the Bridger and Uinta Formations. Most of the clastic sediments deposited in the type areas of the Bridger and Uinta Formations were derived from Paleozoic sedimentary rocks and Precambrian quartzites and metaquartzites in the Uinta Mountains.

3. At least one basinwide unconformity is present within the Washakie Formation; none is recognized in the Bridger and Uinta Formations.

4. The intertonguing relationships of the Bridger, Washakie, and Uinta Formations with the upper part of the Grean River Formation are physically similar but chronologically different in all three formations. As shown in figure 2, the uppermost beds of the Green River Formation intertongue with progressively younger Eocene rocks in a clockwise direction around the Uinta 


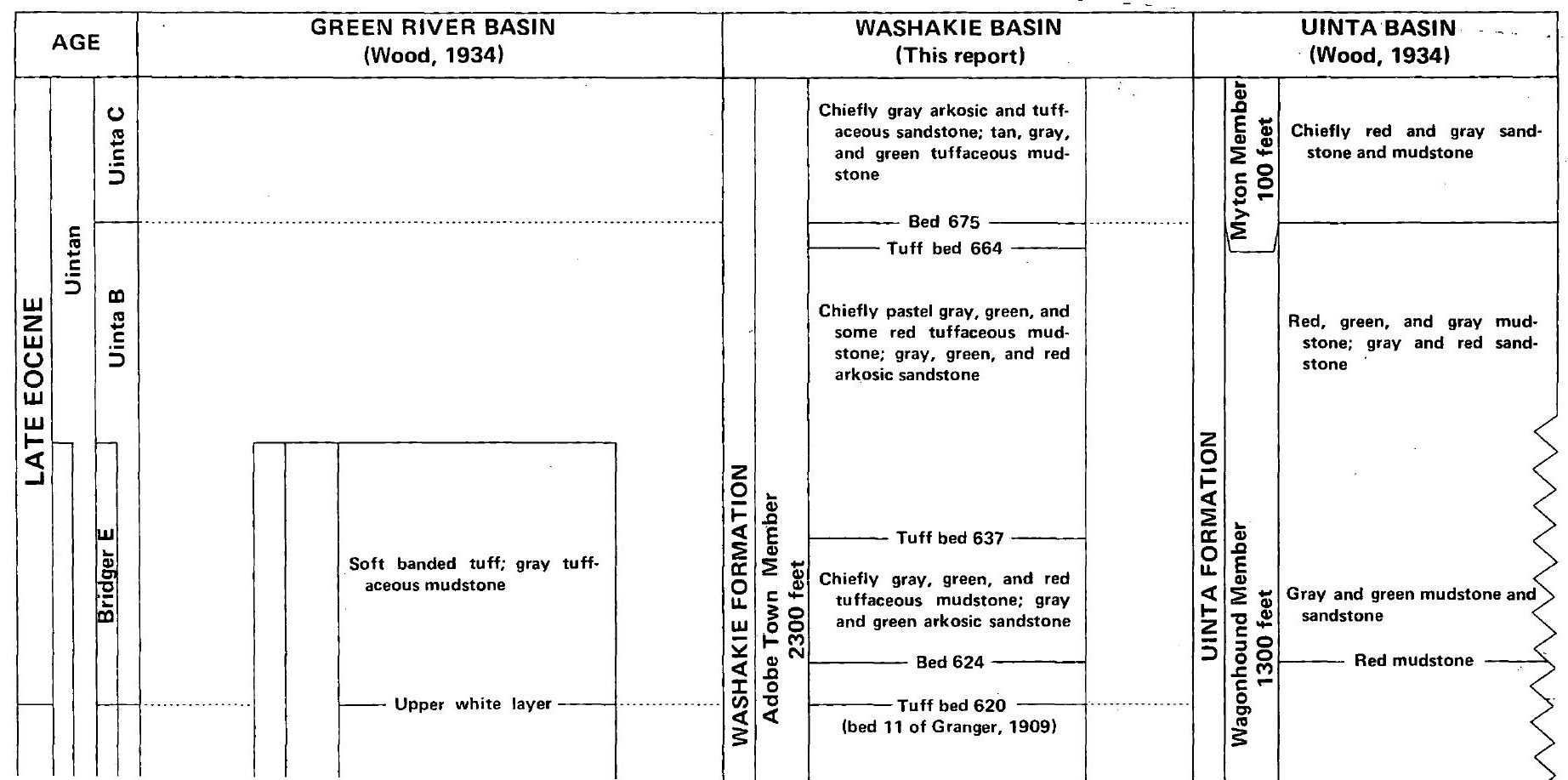




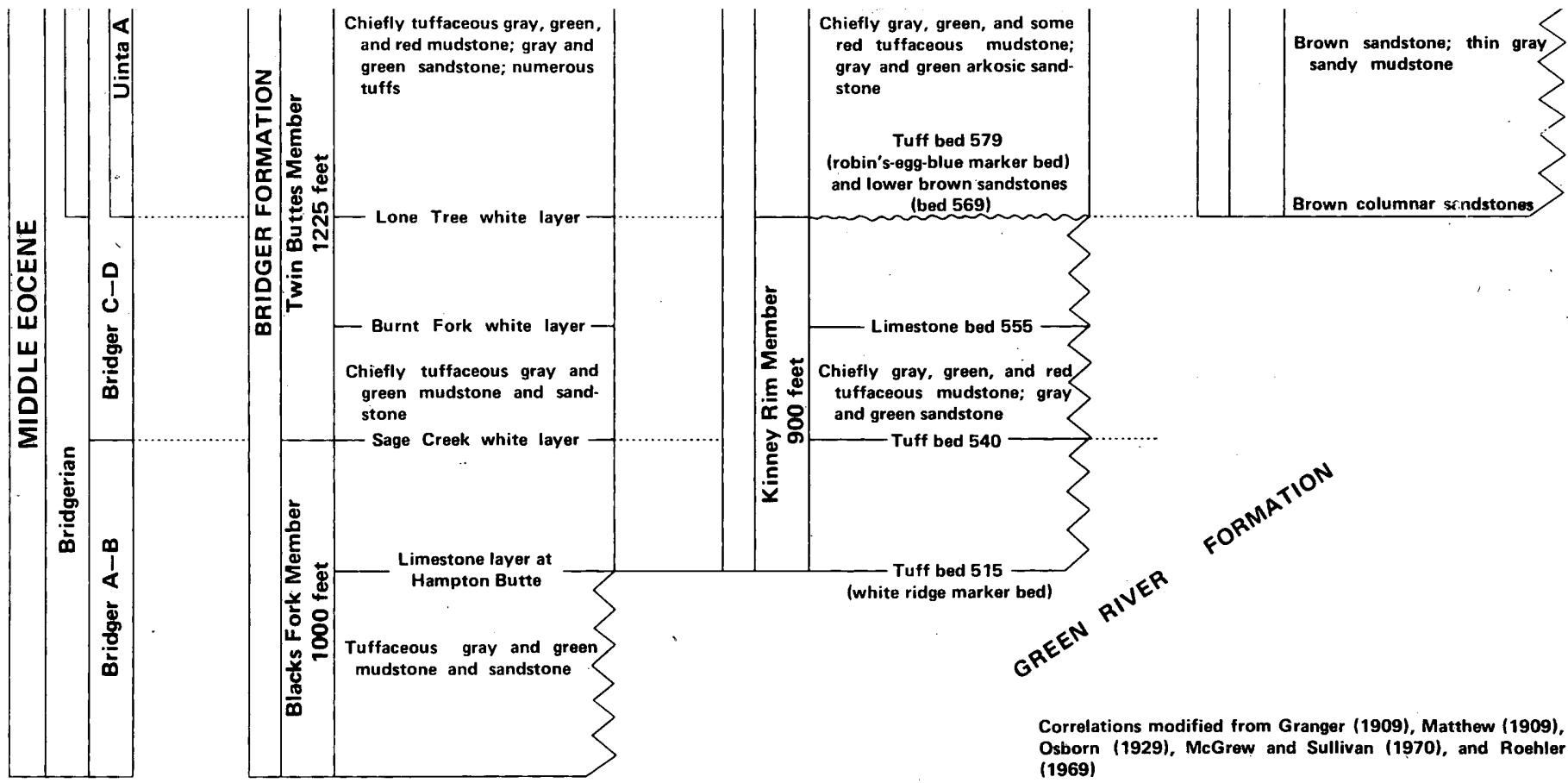

FIGURE 2.-The generalized lithologies, stratigraphic correlations, and ages of the Green river, Washakie, and Uinta Formations, and their intertonguing relations with the upper part of the Green River Formation. 
Mountains from the Green River Basin to the Washakie Basin to the Uinta Basin. (See index map, fig. 1.) The result is a distinct change in the basic stratigraphic relationships of timeequivalent rocks from basin to basin. For instance, the Uinta Formation contains a thick section of saline lacustrine rocks (placed in the Green River Formation by some authors) that are not represented in the Washakie and Bridger Formations.

5. The Washakie Formation has a distinct succession of beds that are recognized and correlated everywhere in the Washakie Basin. Although certain beds are generally believed to be correlative, as shown in figure 2, neither the overall Washakie succession nor any single bed has been positively correlated to beds in the other formations.

Other significant differences between the Washakie and Bridger Formations were noted by Osborn (1881, p. 12-13), Sinclair (1909, p. 25), Wheeler (1961, p. 15), and Bradley (1964, p. A54).

\section{WASHAKIE FORMATION}

The Washakie Formation crops out in an area of about 680 square miles in the central part of the Washakie Basin (fig. 1), where it has a maximum thickness of about 3,200 feet. The formation is principally a sequence of irregularly interbedded gray and green mudstone; gray, green, or brown tuffaceous and arkosic sandstone; and minor thin beds of tuff, limestone, conglomerate, shale, and siltstone. Sandstone in the formation is generally crossbedded and lenticular; a few beds have persistent parallel bedding. Some red mudstone and sparse thin gray limestone beds that contain oolites, algae, and mollusks are found throughout the formation.

The Washakie Formation is divided into two members. The lower $900 \pm$ feet is herein named the Kinney Rim Member and is separated from the upper 2,300 \pm feet, herein named the Adobe Town Member, by a basinwide unconformity. The members are also broadly separable on the basis of minor lithologic differences summarized in table 1. Four stratigraphic sections of the Washakie Formation, including type sections for the Kinney Rim and Adobe Town' Members, are described under "Type Sections and Principal Reference Sections."

\section{KINNEY RIM MEMBER}

The name Kinney Rim Member of the Washakie Formation is applied to fluvial rocks of middle Eocene age exposed along the lower east slopes of Kinney Rim in the western part of the Washakie Basin; where the member is nearly 900 feet thick. It 
TABLE 1.-Lithologic differences between the Kinney Rim and Adobe Town Members of the Washakie Formation in the Washakie Basin, Wyo.

\begin{tabular}{|c|c|c|}
\hline Lithologic unit & Kinney Rim Member & Adobe Town Member \\
\hline Mudstone & $\begin{array}{l}\text { Chiefly dark olive to dark } \\
\text { green; mostly clayey or } \\
\text { silty; partly tuffaceous; } \\
\text { weathers to drab nonre- } \\
\text { sistant slopes and val- } \\
\text { leys. }\end{array}$ & $\begin{array}{l}\text { Pastel shades of gray, } \\
\text { green, or pink; mostly } \\
\text { sandy; very tuffaceous; } \\
\text { weathers to resistant } \\
\text { steep-sloped pastel bad- } \\
\text { lands. }\end{array}$ \\
\hline Sandstone --. & $\begin{array}{l}\text { Gray; mostly fine to me- } \\
\text { dium grained; partiy } \\
\text { arkosic and tuffaceous; } \\
\text { weathers to low brown } \\
\text { ridges. }\end{array}$ & $\begin{array}{l}\text { Typically gray, green, or } \\
\text { brown; coarse grained; } \\
\text { mostly arkosic and tuf- } \\
\text { faceous; weathers to } \\
\text { resistant gray, green or } \\
\text { brown ridges and ledges. }\end{array}$ \\
\hline Tuff -- & $\begin{array}{l}\text { Mostly light to medium } \\
\text { gray or tan. }\end{array}$ & $\begin{array}{l}\text { Tan, gray, or green. Tuffs } \\
\text { thicker and more num- } \\
\text { erous in Adobe Town } \\
\text { Member. }\end{array}$ \\
\hline Andesite pebbles_- & None identified & $\begin{array}{l}\text { Forms a conglomerate bed } \\
\text { at one horizon; minor } \\
\text { constitutents in several } \\
\text { conglomerates composed } \\
\text { chiefly of chert. }\end{array}$ \\
\hline
\end{tabular}

is composed mainly of gray, green, and some red mudstone and interbedded gray and gray-green, very fine to fine grained sandstone; and occasional thin beds of gray limestone, algal limestone, gray limy siltstone, and light-gray to white tuff. Weathered outcrops in the type section are characterized by resistant ridges of white tuff, gray limestone, and brown sandstone separated by valleys eroded in drab-gray mudstone.

The contact of the Kinney Rim Member and the underlying Laney Shale Member of the Green River Formation along Kinney Rim is arbitrarily placed at the base of a persistent limy tuff informally called the white ridge marker bed (bed 515, figs. 1 and 3). The Laney Shale Member for 200 feet below the white ridge marker bed is olive-green fluvial mudstone and interbedded lacustrine sandstone and limestone. The white ridge marker bed was chosen as the base of the member because it makes up the lowermost persistently mappable unit in an otherwise dominantly fluvial section.

The upper contact of the Kinney Rim Member is the base of a series of brown sandstone beds which overlie an unconformity that divides the Washakie Formation into two parts. These beds nearly everywhere weather to a low brown ledge or rim referred to as the lower brown sandstones or lower brown sandstone rim. Beds adjacent to the unconformity are not noticeably discordant. A thinning and wedging out of beds by truncation below the lower brown sandstones is apparent, however, on small-scale aerial 


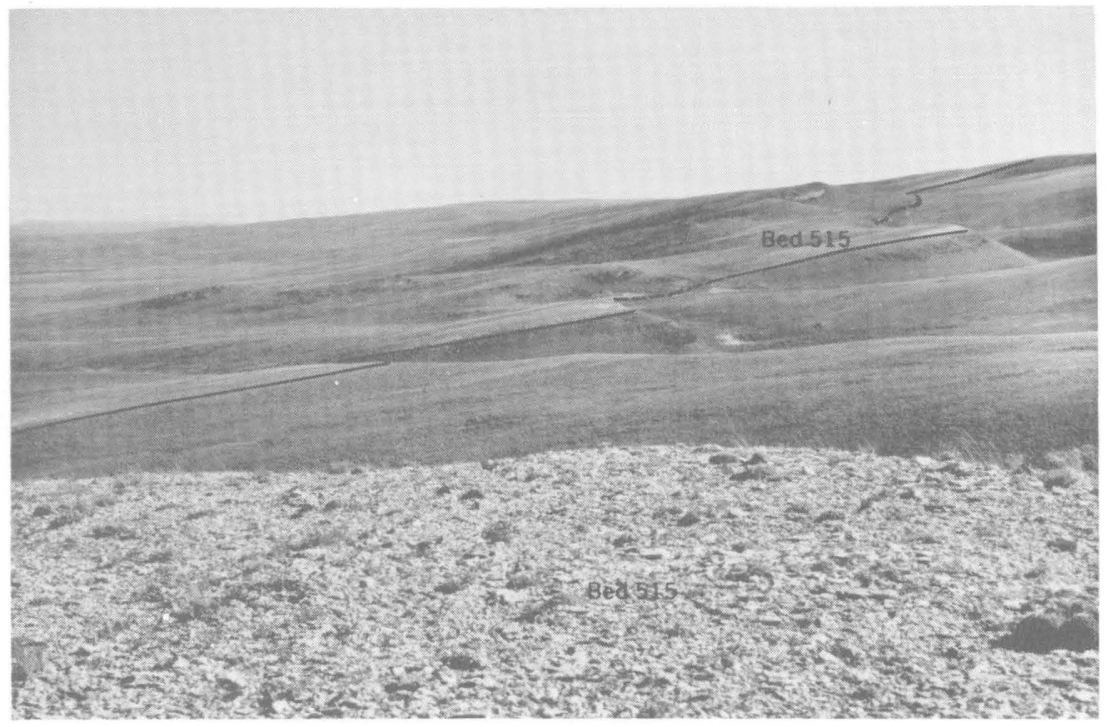

Figure 3.-The white ridge marker bed (bed 515, fig. 1) on the east slopes of Kinney Rim in secs. 26 and 36, T. 15 N., R. 100 W. The contact of the Kinney Rim Member of the Washakie Formation and the Laney Shale Member of the Green River Formation is located at the base of the white ridge marker bed shown in the foreground and in the distant slopes.

photographs of the northern and southern parts of the basin. The entire Kinney Rim Member is missing where the section below the lower brown sandstones is well exposed in the eastern part of the basin. Erosion there prior to deposition of the Adobe Town Member cuts deeply into the underlying Laney Shale Member of the Green River Formation.

Several thin persistent limestone and tuff beds in the interval between beds 516 and 559 form major reference horizons which are mappable on aerial photographs and which are correlatable for miles in outcrops on the lower east slopes of Kinney Rim. The lower red beds (beds 560-564) weather to a poorly exposed, topographically low valley between hogback ridges. The white ridge marker bed, as well as marking the lower contact, is also an important datum for correlating strata in the Kinney Rim Member in the western part of the basin. None of the marker beds in the lower part of the Kinney Rim Member have been identified in the eastern part of the basin in the laterally equivalent Laney Shale Member of the Green River Formation.

The Adobe Town Member takes its name from Adobe Town 
(fig. 1), where the upper part of the Washakie Formation is well exposed. The member is composed of green, gray, and red tuffaceous mudstone alternating with gray fine- to coarse-grained tuffaceous and arkosic sandstone and minor thin beds of green shale, light-gray and green tuff, gray siltstone, and conglomerate. The member unconformably overlies the Kinney Rim Member in the western part of the basin and unconformably overlies the Laney Shale Member of the Green River Formation in the eastern part of the basin. A maximum thickness for the Adobe Town Member, compiled from a type section and two principal reference sections, is nearly 2,300 feet in the southwestern part of the basin, but the member may be thicker in the subsurface near the center of the basin where no stratigraphic data are available. With only a few exceptions; beds in the Adobe Town Member thicken from east to west across the basin. An interval thickens rapidly near the top of the member (beds 645-660) ; a fact that suggests an unconformity may be present at the base of the overlying sandstones that cap Haystack Mountain in the northeastern part of the basin. Beds of the Adobe Town Member compose the youngest strata exposed in the center of the Washakie Basin, but the Browns Park Formation of Miocene and Pliocene (?) age unconformably overlies parts of both the Adobe Town and Kinney Rim Members for several miles near the north boundary of T. 12 N., Rs. 96, 97, and 98 W., at the south edge of the basin.

The Adobe Town Member has within it stratigraphically important tuff, andesite pebble conglomerate, and red or green marker beds that are especially useful for identifying stratigraphic levels and for making stratigraphic correlations in the central part of the basin. The lowermost of these beds, informally called the robin's-egg-blue marker bed or robin's-egg-blue tuff, is a 4- to 25-foot-thick sandy tuff bed that immediately overlies the lower brown sandstones (fig. 4). It has a distinctive lightblue-green color that makes the bed easy to recognize nearly everywhere in the basin, except in a few places where it is one of a series of blue-green tuff beds, which may have an overall thickness of as much as 100 feet. Red beds (beds 596-603) are thick and easily correlated in the middle of the member in outcrops in the southern part of the basin, but they thin and are difficult to recognize in the northern part of the basin at Haystack Mountain. Bed 620 is the light-gray or white tuff bed used by Granger (fig. 1) as a time line to separate rocks of Washakie A age from those of Washakie B age. Bed 620 normally overlies a sandstone rim below the Adobe Town Rim, except in the south- 


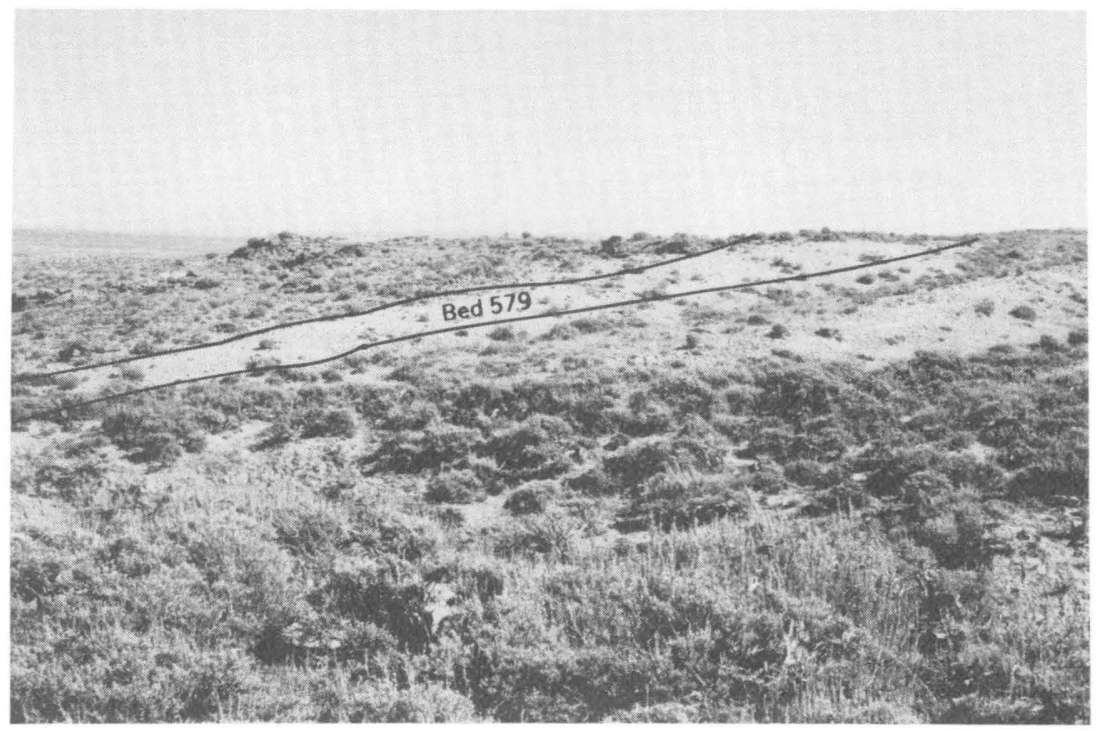

Figure 4.-The robin's-egg-blue marker bed (bed 579, fig. 1) in the southwest part of sec. 15, T. 14 N., R. 99 W. This light-blue-green tuff bed is correlatable in outcrops nearly everywhere in the Washakie Basin.

western part of the basin and in places in the southeastern part of the basin where the tuff is either covered or missing. Bed 633 and the adjacent sandstone beds are identified by their olivegreen color and by an abundance of fossil wood fragments and fossil logs. An andesite conglomerate bed (bed 636) seems to have basinwide distribution and is characterized by small varicolored uniformly well rounded ellipsoidal pebbles. Andesite pebbles are not restricted to this bed, however, but are a minor constituent in other conglomerates above and below bed 636 that are composed mostly of chert. The rose-red marker bed (bed 644 ) is mainly rose-weathering tuffaceous mudstone and is a readily identified marker in outcrops in the southeastern part of the basin. It is thickest, about 200 feet, in the western part of T. 14 N., R. $96 \mathrm{~W}$. The rose-red marker is visible in the upper slopes at the eastern end of Haystack Mountain, where it is situated between bright-green mudstones, but it thins and wedges out westward in the north slopes of the mountain (fig. 1).

\section{OUTCROPS}

The Kinney Rim Member is well exposed only in the western part of the Washakie Basin. The best exposures of the lower part of the Adobe Town Member are at Haystack Mountain in the 
north-central part of the basin; the upper 300 feet of the Adobe Town Member is preserved only at Adobe Town and for a few miles southwest of Adobe Town in the central-southwest, structurally lowest, part of the basin.

The area of the Washakie Basin underlain by the Washakie Formation has a few good roads, in addition to several trails that are passable only by four-wheel drive vehicles. For miles between these roads and trails, outcrops are inaccessible, except on foot, which makes stratigraphic correlations exceedingly difficult. Fortunately, outcrops of the formation weather to easily recognized landforms that are useful in locating stratigraphic levels. Some of these landforms and other important outcrop areas are described in the following paragraphs.

\section{HAYSTACK MOUNTAIN}

The dominant feature of the landscape in the north-central part of the basin is Haystack Mountain, a large arcuate ridge that trends eastward for almost 10 miles (fig. 1). Relief on Haystack Mountain is greatest at its east end where terraced badland slopes rise precipitously for more than 500 feet above adjacent plains (fig. 5). The relief on Haystack Mountain decreases westward

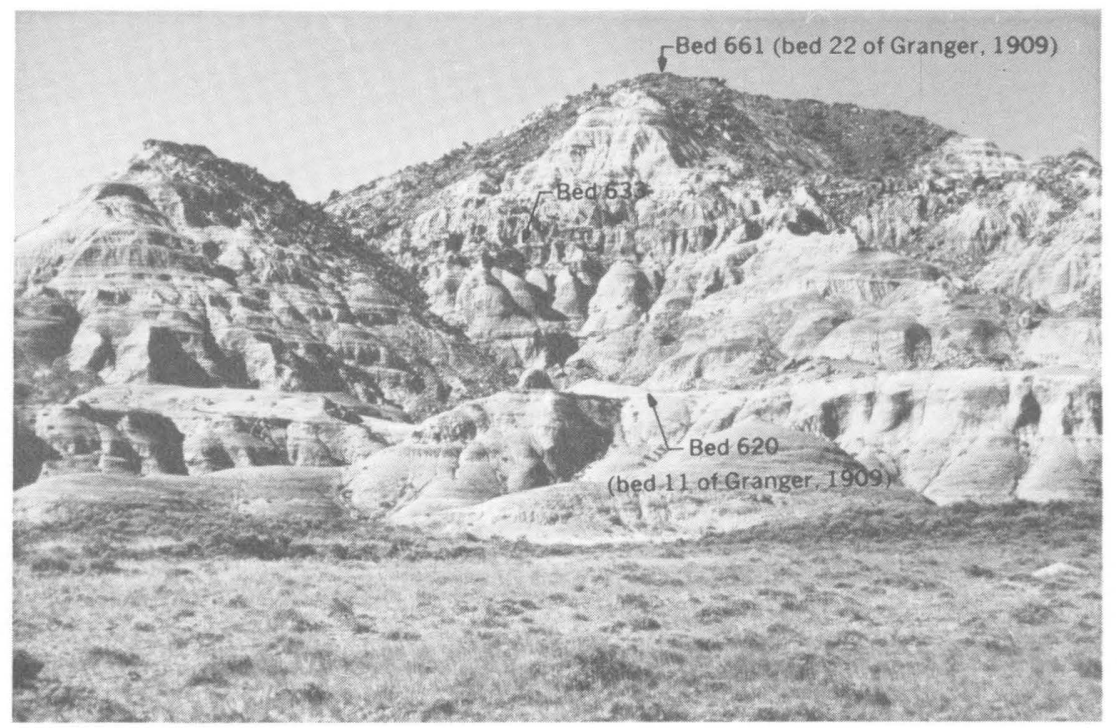

Figure 5.-Outcrops cf the Adobe Town Member of Washakie Formation at the east edge of Haystack Mountain in the southwestern part of sec. 30, T. 17 N., R. 95 W. 
along the mountain, and badlands are present on more gentle slopes. Bed 620 , a white tuff, is recognizable nearly everywhere in the lower east slopes of the mountain; ledgy sandstone near the center of the east slopes characterizes bed 633; and arkosic sandstone including bed 661 caps the east slopes.

\section{ADOBE TOWN}

The name Adobe Town has been applied to a 40- to 50-square mile area near the geographic center of the basin where erosion has created unusual badland configurations (Granger, 1909, p. $17)$. This remote area is bounded on the west by a broad relatively undissected gently west-sloping plain, which is covered by sand dunes and alluvium. The flat terrain of the plain breaks abruptly at Adobe Town Rim into a maze of badlands that form small basins, ledges, alcoves, and reentrants at lower elevations east of the rim. From a few hundred feet to about 1 mile east of Adobe Town Rim, at still lower elevations, the badlands give way to a rolling sand dune-covered plain upon which are located small isolated haystack- or house-shaped outliers (fig. 6). These give the area its name.

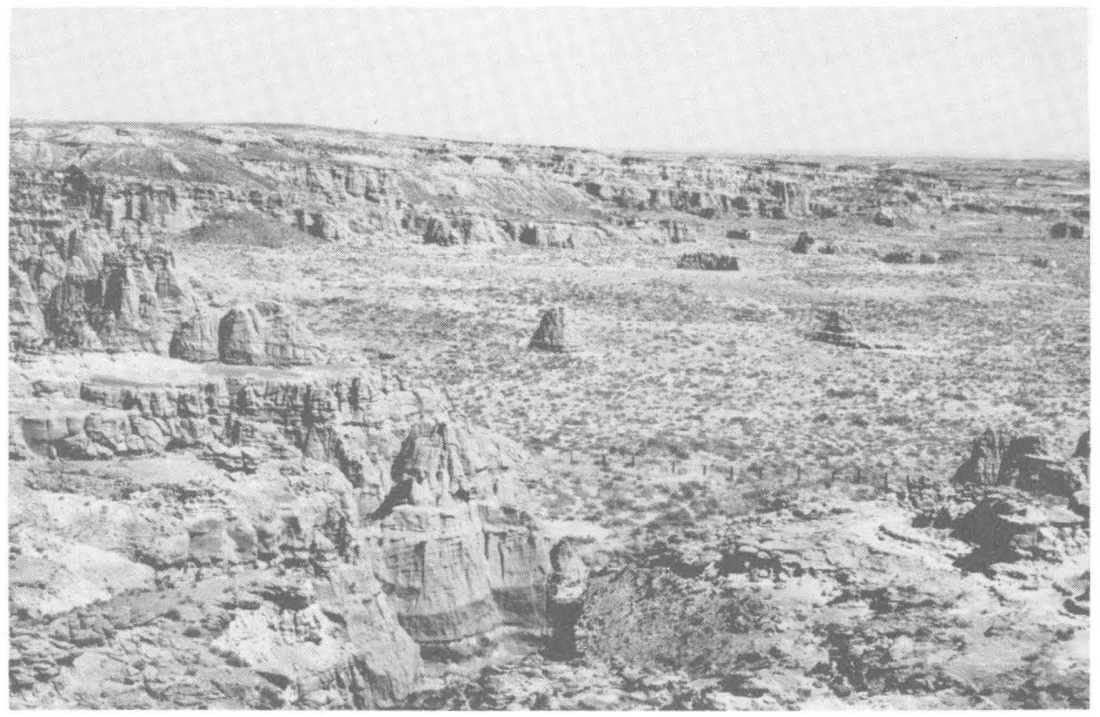

Figure 6.-Outcrops of the Adobe Town Member of the Washakie Formation at Adobe Town. The view is northeast from Adobe Town Rim in the northeastern part of sec. 13 , T. 15 N., R. 98 W. Beds in the foreground are approximately the level of bed 670 . 
EASTERN, NORTHERN, AND SOUTHERN WASHAKIE BASIN

The identification of beds in the Washakie Formation in the eastern, northern, and southern parts of the basin is aided by the presence of three major ridges, or rims, spaced 2-5 miles apart, that rise 100-300 feet above adjacent outcrops and covered areas. The rims are capped by thick resistant arkosic or tuffaceous sandstones that in ascending order are referred to as the lower brown sandstones (fig. 7), the sandstone rim below Adobe Town Rim (fig. 8), and the sandstones that cap Haystack Mountain (fig. 9). The escarpments face outward from the center of the basin and are irregularly eroded to steep badland slopes. The desolate terrain on $3^{\circ}-5^{\circ}$ dip slopes between the rims is largely covered by vegetated longitudinal sand dunes and alluvium; between the covered areas the Washakie Formation is exposed in the forms of badlands and minor ridges. The three major rims are broken into segments in a few places by dry washes that are tributary to Barrel Springs Draw in the east and to Sand Creek in the southeast.

\section{WESTERN WASHAKIE BASIN}

The Washakie Formation is mostly covered by alluvium and sand dunes in the western part of the basin. Beds there normally

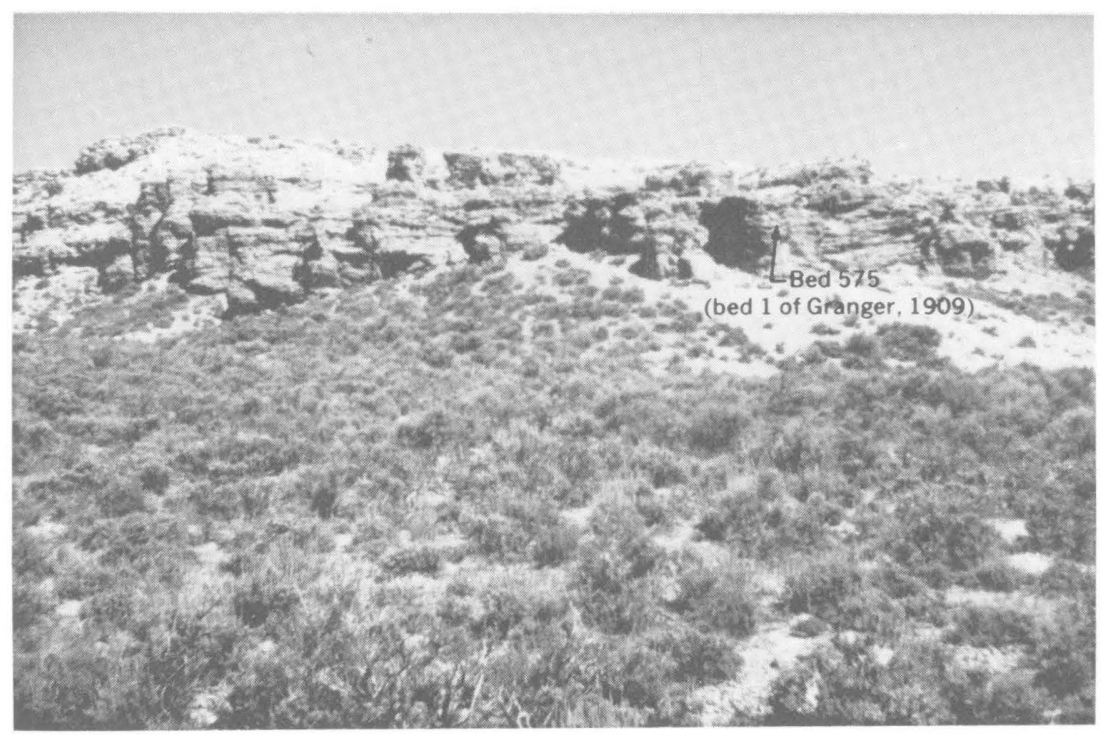

FIGURE 7.-Outcrops of the lower brown sandstones in the north slope of Wild Rose Draw in the northern part of the Washakie Basin in sec. 13, T. 17 N., R. 96 W. 


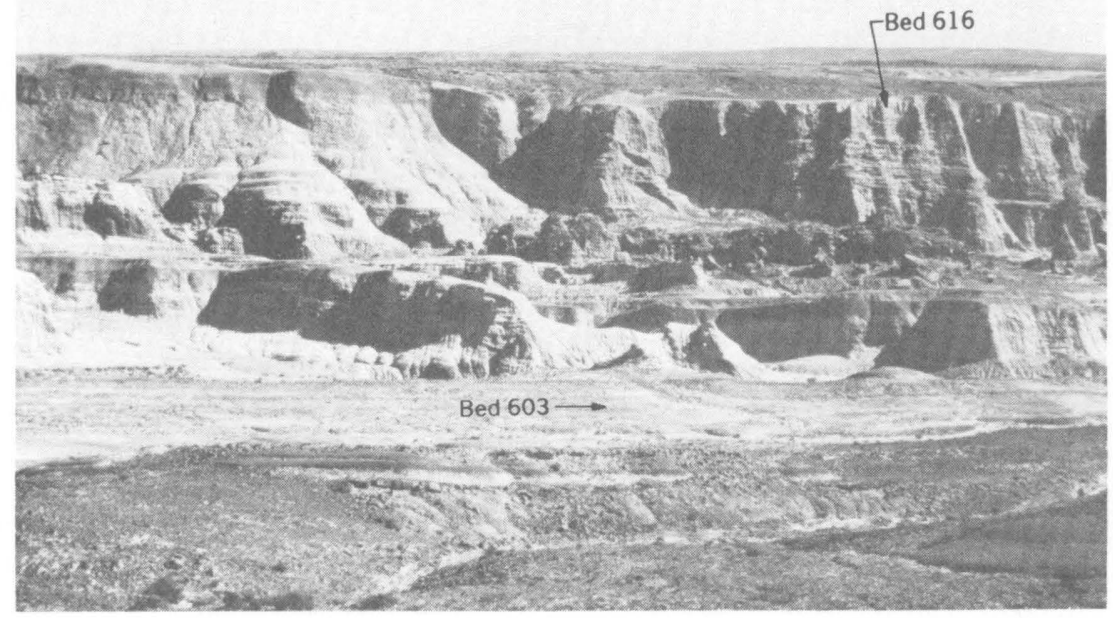

FIgURE 8.-The sandstone rim below Adobe Town Rim in the southern part of the Washakie Basin. View is northeast from the northwestern part of sec. 29 , T. 13 N., R. 98 W. Beds 601 to 619 were measured in the outcrops shown in the left side of the photograph. The section between beds 603 and 616 is about 150 feet thick.

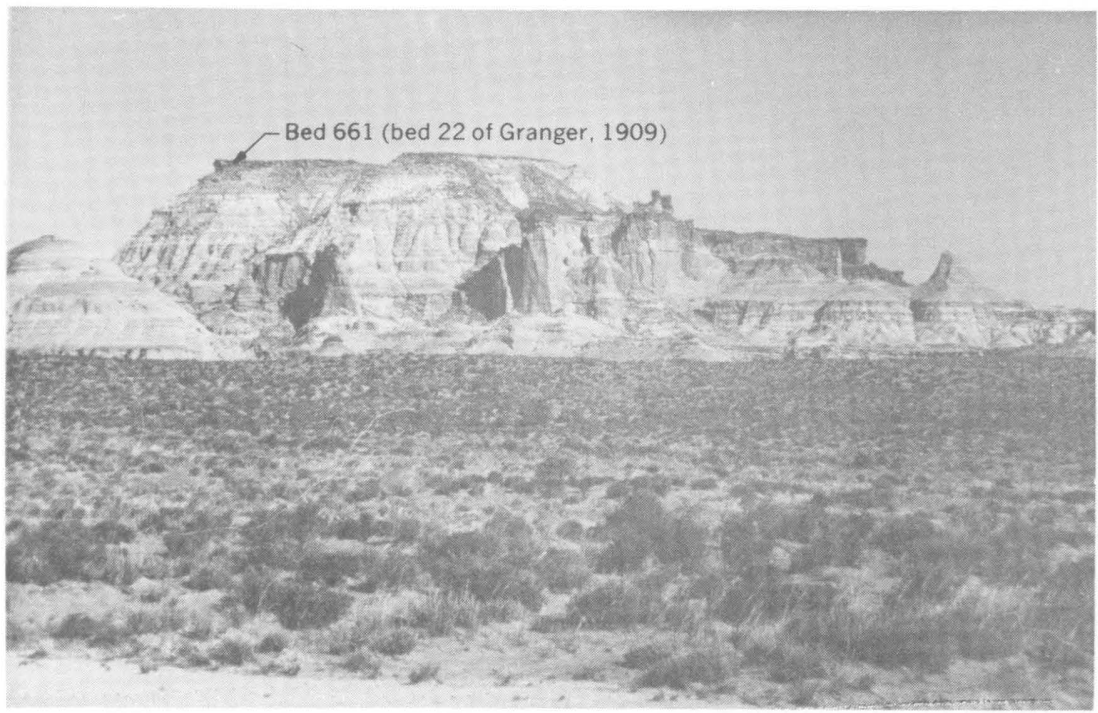

Figure 9.-An outlier along the rim capped by the same arkosic sandstones of the Adobe Town Member that cap Haystack Mountain, here shown in the southern part of the Washakie Basin. View is northwest from the northeastern part of sec. 16, T. 13 N., R. 97 W. Relief between the plain in the foreground and the top of the outlier is more than 300 feet. 
dip $3^{\circ}-6^{\circ}$ E., but dips of $6^{\circ}$ to at least $25^{\circ}$ occur in a narrow southeast-trending band of outcrops along the lower east slopes of Kinney Rim in a series of persistent, topographically low hogback ridges. Eastward from these ridges small areas of badlands alternate with low sage-covered hills. Desert pavement consisting of polished flattened varicolored chert and quartzite pebbles is common in local wind-deflated areas between vegetated sand dunes (fig. 10). The three sandstone rims that characterize the eastern, northern, and southern exposures of the formation are inconspicuous or missing.

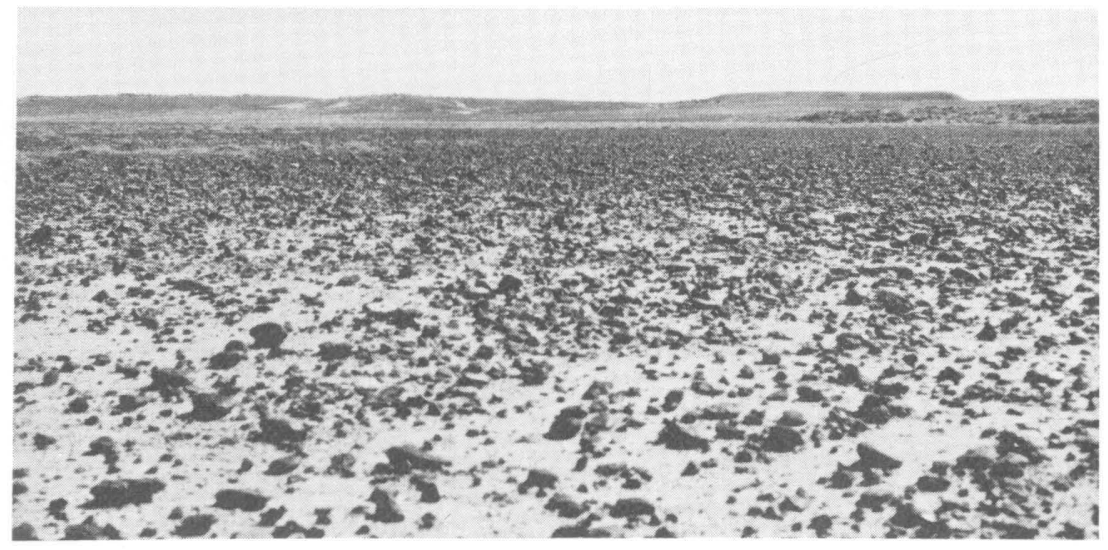

FIGURE 10.-Desert pavement in the western part of the Washakie Basin in sec. 7, T. 14 N., R. 98 W. The larger pebbles in the foreground are about 2 inches in diameter.

\section{SOURCE AREAS AND MINERALOGY}

Deposition of the Washakie Formation was mainly by aggrading distributary streams in a slowly subsiding basin. The primary source area for detrital sediments was the Sierra Madre east of the Washakie Basin. Varicolored chert and gray or green quartzite clasts derived from the Mesozoic and Paleozoic rocks on the west flank of the Sierra Madre have been found in nearly every pebble conglomerate in the formation. Sandstone becomes more and more feldspathic from the base to the top of the formation, a relation that suggests that erosion increasingly enlarged exposures of the plutonic core of the Sierra Madre during the Eocene. In some sandstone in the Adobe Town Member, green feldspars are so abundant that they impart a green color to outcrops; feldspars in other beds impart slightly pink or gray hues. Sandstone in both members has an average mineral composition of 60-70 percent quartz and feldspar grains, 25-35 percent silt 
and clay, 2-3 percent soluble calcium carbonate, and 2-3 percent heavy minerals. The heavy mineral suite (specific gravity greater than 2.85) has an average composition of 50-65 percent green or green-brown hornblende, 10-20 percent blue-green hornblende, 10-35 percent augite, 3 percent garnet, and 2 percent zircon, mica, and magnetite (Roehler, 1970, p. D186-D187). Hornblende is most abundant in the Kinney Rim Member, whereas augite is most abundant in the Adobe Town Member. Interbedded with the detrital sediments in the formation are numerous air-laid tuff beds and, at one horizon, a fluvial andesite pebble conglomerate (bed 636), the pebbles in which came from a distant volcanic field, possibly the Absaroka Mountains in northwestern Wyoming. Many tuff beds were reworked by streams prior to burial and lithification. The tuffs are partly glass but mostly eruptive dacite according to Johannsen (1914, p. 211-219), but he added that because of a large amount of quartz the "dacite tuffs may be formed of the materials of an andesite, with sedimentary quartz grains." X-ray diffraction data from samples I collected indicate that the tuffs are largely vitric tuffs altered to the zeolites clinoptilolite and mordenite. Clinoptilolite is particularly abundant in the robin's-egg-blue marker bed (bed 579). The clay minerals illite, kaolinite, and montmorillonite occur as constituents of rocks throughout the formation.

\section{CORRELATIONS}

On the basis of electric logs from four of about eight oil and gas test wells that are usable for correlations of the Washakie Formation in the central part of the Washakie Basin, and data from well sample logs (not shown) and two surface sections, a west-east surface-subsurface cross section of the basin was prepared (pl. 1). In this basin electric log correlations are difficult to make, because of the following factors: wells are scarce and widely spaced; the formation is composed largely of lenticular fluvial rocks; the formation has at least one major intraformational unconformity; most beds change thickness abruptly; and, in the lower part, beds intertongue extensively with those in the Green River Formation. For these reasons a persistent easily correlatable bed (bed 454a) in the underlying Laney Shale Member of the Green River Formation was used as a datum on plate 1. The eastward truncation and wedging out of the Kinney Rim Member is readily apparent in stratigraphic sections measured on the east and west sides of the basin; plate 1 illustrates this relationship in the subsurface between two such surface sections.

Surface correlations of the Washakie Formation in a northeast 
direction across the basin are illustrated by composite graphic sections on plate 2. Plate 2 also shows generalized lithologies, bed numbers, age, stratigraphic relations, types of fossils and their stratigraphic positions, key beds, and key reference horizons.

\section{AGE AND FAUNAL RELATIONS}

The correlations of stratigraphic units in the Bridger, Washakie, and Uinta Formations (fig. 2) are based upon the ages indicated by fossil mammals. Fossil mammals are numerous and widely distributed in the Washakie Formation (fig. 1, pl. 2, and table 2). The fossils and their age relations have been studied over a long period of time by Osborn $(1881$, p. 9-15; 1929, p. 85-91), Scott (1890, p. 462-470), Granger (1909, p. 12-23), Simpson (1933, p. 114, fig. 4), Wood (1941, p. 10 and 34, pl. 1), McGrew (1951, p. 54), Gazin (1959, p. 136), and Wheeler (1961, p. 13-15). A detailed list of mammals from the Washakie Formation was published by Osborn $(1929, p .89)$. The consensus of the above vertebrate paleontologists is that rocks below bed 620 (Washakie A of Granger, 1909; see fig. 12) are the same age as Bridger C-D of the Bridger Formation in the Green River Basin in southwest Wyoming, and that the rocks overlying bed 620 (Washakie B of Granger, 1909) are the same as Uinta A and Uinta B of the Uinta Formation in the Uinta Basin in Utah. Most fossil mammal collections from the Washakie Formation have been inadequately located geographically and stratigraphically. One result of the present work has been to place some of the older collecting sites, as well as some new ones, in an easily recognized stratigraphic framework.

Fossil mammals collected recently by me and by W. D. Turnbull modify many of the previous concepts concerning the age and stratigraphic relations of the Washakie Formation. The boundaries of divisions of the provincial ages of rocks (that is, Bridger A-B, C-D, E; Uinta A, B, C, etc.) are frequently placed on tuff beds or other widespread marker beds that are located between distinct faunal changes in the stratigraphic succession. The tuff or marker beds are then used as time lines in stratigraphic correlations. The Bridger A-B and Bridger C-D time line shown on plate 2 is tentatively placed on the top of tuff bed 540 because of its stratigraphic position, widespread distribution, and the age relations suggested by fossil mammals. W. D. Turnbull (written commun., Jan. 1971) believes that small faunas collected at localities 1 and 2 (pl. 2 and table 2), which are about 150 and 75 feet stratigraphically below bed 540 , respectively, and which consist of only fragmentary remains, have Bridger A-B aspects. 
Those from localities 3 and 4, which are estimated to be between 200 and 300 feet above bed 540, are definitely Bridger C-D. The occurrence of Bridger A-B mammals at localities 1 and 2 is important, because rocks of that age have not previously been identified in the Washakie Formation. Rocks of Bridger A-B age were formerly believed to be represented only within the underlying Green River and Wasatch Formations.

Granger (1909, p. 22-23) has shown that Washakie A, which includes the lower brown sandstones at its base, corresponds faunally to Bridger C-D in the Bridger Basin (Green River Basin). Osborn (1929, p. 85-86) presented additional evidence to indicate that the lower brown sandstones were deposited contemporaneously with rocks of Bridger $\mathrm{D}$ age in the Bridger Formation and with rocks of Uinta A age in the Uinta Formation. The evidence of Osborn and the fossil record in the Washakie Formation raise speculation as to the validity of the term Uinta A. The range and abundance of Metarhinus, a titanothere, in the basal part of both Washakie B and Uinta B, and some other faunal evidence, suggest that Washakie $B$ and Uinta $B$ are the same age. Furthermore, Granger's (1909, p. 22) demonstration of the close similarities of the mammalian genera in Uinta $A$ and Uinta $B$ to Washakie $B$ is no longer completely valid because Uinta A, as revised by Osborn (1929, p. 91), is nonfossiliferous; therefore, the close similarities exist between only Uinta $B$ and Washakie B. The faunas from localities $7,8,9$, and 10 (fig. 1, pl. 2 , and table 2) leave little doubt that the section for several hundred feet below the lowermost Uinta $B$ beds in the Washakie Formation is time equivalent to the upper part of Bridger $C-D$ in the Green River Basin. Thus, paleontological evidence indicates either that rocks of Uinta $A$ age are missing in the Washakie Basin or, more likely, that they are equivalent to the rocks of Bridger C-D age.

The assignment of beds 676-708 (pl. 2) to Uinta $\mathrm{C}$ is speculative-it is based on lithologic differences in the rocks signifying a slight change in sedimentary regime. Rocks assigned to Uinta $\mathrm{C}$ have a few thin beds of dark-brown carbonaceous shale in the upper part; they weather very light gray or very light tan in contrast to darker weathering noncarbonaceous underlying rocks. The rocks of Uinta $\mathrm{C}$ overlie the sandstones that cap Haystack Mountain; below these sandstones Cope (1873) (loc. 18, pl. 2, and table 2) apparently collected the iype Eobasileous cornutus, a late Uinta B form. The specimens collected at locality 19 (fig. 1, pl. 2, and table 2) are not sufficiently diagnostic to date the beds in that part of the section. 
TABLE 2.-Vertebrate localities and partial list of fauna in the Washakie Formation

[The stratigraphic positions of the localities are shown in fig. 1]

\begin{tabular}{|c|c|c|c|c|c|c|}
\hline \multirow{2}{*}{$\begin{array}{c}\text { Fossil } \\
\text { locality } \\
\text { No. }\end{array}$} & \multirow{2}{*}{$\begin{array}{c}\text { Geographic } \\
\text { position 1 } \\
\text { (see fig. 1) }\end{array}$} & \multirow{2}{*}{$\begin{array}{l}\text { Stratigraphic } \\
\text { bed No. } \\
\text { (see pl. 2) }\end{array}$} & \multirow{2}{*}{ Fauna (partial list) } & \multicolumn{3}{|c|}{ Collection data } \\
\hline & & & & Collector & Year & Reference \\
\hline 1 & $\begin{array}{l}175 \text { fel, } 100 \text { fnl., sec. } 17, T . \\
14 \text { N., R. } 99 \text { W. }\end{array}$ & 527 & Hyrachyus cf. H. modestus & W. D. Turnbull -- & 1970 & Unpub. data. \\
\hline 2 & $\begin{array}{l}850 \text { fwl, } 225 \text { fsl, sec. } 18, T \text {. } \\
15 \text { N., R. } 99 \text { W. }\end{array}$ & 533 & $\begin{array}{l}\text { Sciuravus cf. S. nitidus } \\
\text { (probable primitive form). }\end{array}$ & 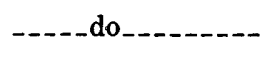 & 1970 & Do. \\
\hline 3 & 175 fwl, $200 \mathrm{fsl}$, sec. 32 , T. & 565 & Hemiacodon gracilis & P. O. McGrew and & 1958 & Do. \\
\hline 4 & 2,000 fwl, $1,500 \mathrm{fnl}$, sec. 1 , & 569 & $\begin{array}{l}\text { Microsyops cf. M. schlosseri } \\
\text { Hurachuus sp. }\end{array}$ & H. W. Roehler -- & 1970 & Do. \\
\hline 5 & $\begin{array}{l}\mathrm{SE}_{95} \mathrm{~W} \text { W. } \\
92, \mathrm{~T} .16 \mathrm{~N} ., \mathrm{R} .\end{array}$ & $569-579$ & Stylinodon sp & W. D. Turnbull -- & 1958 & Do. \\
\hline 6 & $\begin{array}{l}\text { Near sec. } 27, T, 16 \text { N., R. } \\
95 \text { W. }\end{array}$ & $569-579$ & $\begin{array}{l}\text { Dinoceras cuneum, Tinoceras } \\
\text { affine. }\end{array}$ & O. C. Marsh _...-- & $1884(?)$ & $\begin{array}{l}\text { Marsh }(1885 \\
\text { p. 198) }\end{array}$ \\
\hline 7 & $\begin{array}{c}\text { SW } 1 / 4 \text { NE } 1 / 4 \text { SW } 1 / 4 \text { sec. } \\
18, \text { T. } 13 \text { N., R. } 95 \text { W. }\end{array}$ & About 595 & Hyopsodus cf. H. despiciens -- & H. W. Roehler -- & 1968 & Unpub. data. \\
\hline 8 & $\begin{array}{l}\text { SW } 1 / 4 \text { SW } 1 / 4 \text { SW } 1 / 4 \text { sec. } \\
20, \text { T. } 13 \text { N., R. } 98 \text { W. }\end{array}$ & 597 & Hyopsodus sp., Orohippus sp - & W. D. Turnbull -- & 1969 & Do. \\
\hline 9 & $\begin{array}{l}\text { NE } 1 / 4 \text { SE } 1 / 4 \text { sec } 19, \text { T. } 16 \\
\text { N., R. } 97 \text { W. }\end{array}$ & About 605 & $\begin{array}{l}\text { Microfauna collected from } \\
\text { anthills. }\end{array}$ & --.-- do & 1958 & Do. \\
\hline 10 & $\begin{array}{l}\text { Do } \\
\text { About sec } 30 \text { or } 31 \text { T } 17 \text {. }\end{array}$ & About 616 & Notharctus sp & 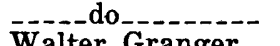 & 1958 & Do. \\
\hline & R. $95 \mathrm{~W}$. & ADout b19 & 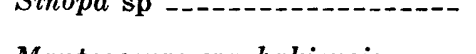 & Walter GI & 19 & p. 207.1000 \\
\hline 12 & Do_-_- & 620 & Manteoceras washakiensis -- & - & 1906 & $\begin{array}{l}\text { Osborn }(1929 \\
\text { p. } 90) \text {. }\end{array}$ \\
\hline 13 & 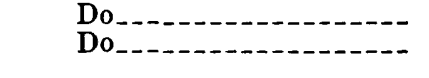 & $\begin{array}{l}635 \\
635\end{array}$ & $\begin{array}{l}\text { Metarhinus earlei } \\
\text { Limnocyon sp }\end{array}$ & - & $\begin{array}{l}1906 \\
1906\end{array}$ & $\begin{array}{l}\text { Do. } \\
\text { Granger } \\
(1909,\end{array}$ \\
\hline 15 & $\begin{array}{c}\text { SW 1/4 SW 1/4 SW } 1 / 4 \text { sec. } \\
\text { 30, T. } 17 \text { N., R. } 95 \text { W. }\end{array}$ & 636 & $\begin{array}{l}\text { Cf. Dolichorhinus, cf. } \\
\text { Metarhinus sp. }\end{array}$ & H. W. Roehler -- & 1968 & ub. data. \\
\hline 16 & $\begin{array}{l}\text { About sec. } 30 \text { or } 31, \text { T. } 17 \text { N., } \\
\text { R. } 95 \text { W. }\end{array}$ & 641 & Dolichorhinus hyognathus & Walter $\mathrm{C}$ & 1906 & $\begin{array}{l}\text { Granger } \\
\text { p. 19). }\end{array}$ \\
\hline 17 & $\begin{array}{l}N W W^{1 / 4} \text { NW } 1 / 4 \text { SW } 1 / 4 \text { sec. } \\
20, \text { T. } 15 \text { N., R. } 96 \text { W. }\end{array}$ & 643 & $\begin{array}{l}\text { Titanothere skull and jaw } \\
\text { fragments. }\end{array}$ & W. D. Turnbull -- & 1970 & Unpub. data. \\
\hline 18 & Mammoth Butte & About 653 & Eobasileus cornutus & E. D. Cope & 1873 & Cope \\
\hline 19 & $\begin{array}{l}\text { E } 1 / 2 \text { sec. } 13, \text { T. } 15 \text { N., R. } \\
98 \text { W. }\end{array}$ & About 677 & $\begin{array}{l}\text { Microfauna, including rodent } \\
\text { skeltons. }\end{array}$ & W. D. Turnbull - & 1957 & ata. \\
\hline
\end{tabular}

${ }_{1}$ Abbreviations fel, fnl, fwl, and fsl indicate feet from east, north, west, and south lines respectively. 


\section{TYPE SECTIONS AND PRINCIPAL REFERENCE SECTIONS}

The Washakie Formation is described in the following composite section that was measured in the southwestern part of the basin; this section is illustrated in columns $A$ and $B$ of plate 2 . The composite section consists of the uppermost part of a more complete section that has been measured across all Eocene rocks in the Washakie Basin; this accounts for the large numbers assigned to the beds beginning with bed 515 at the base of the Washakie Formation. The bed numbers are field numbers which I assigned, and many of them are chiseled or painted yellow on outcrops. Thicknesses were measured by a Jacob's staff, Abney level, and a steel hand tape. Because the Adobe Town Member is nowhere entirely exposed at one locality in the basin, the member is described in three widely spaced sections that were correlated by key beds. The three parts are an upper principal reference section (beds 676-708), the type section (beds 629-675), and a lower principal reference section (beds 569-628).

\section{PRINCIPAL REFERENCE SECTION FOR THE UPPER PART OF THE ADOBE TOWN MEMBER}

[Exposed at Adobe Town in NW $1 / 4$ sec. 30 and SE $1 / 4$ sec. 31, T. 15 N., R. 97 W.]

Top of exposure.

Washakie Formation (part) :

Adobe Town Member:

708 Mudistone, green, silty, blocky, firm

Thickness (feet)

707 Sandstone, gray fine-grained to very coarse grained, 13.0 poorly sorted, subangular, crossbedded; abundant colored grains, argillaceous and calcareous streaks; weathers to nearly vertical slopes

706 Mudstone, green, silty, blocky, hard. Grades upward into gray, fine-grained, argillaceous, soft sandstone -...-..-

705 Sandstone, gray, fine-grained to very coarse grained, poorly sorted, subangular, firm, friable, limonitic crossbedded, partly argillaceous; scattered fish bones and turtle scutes

Mudstone, green, silty, blocky, hard; several very thin black streaks; some interbedded gray-green sandstone. Unit is very fine grained, argillaceous, firm, friable --

703 Silstone, gray-brown, shaly, limonitic, carbonaceous, firm; weathers rust brown

702 Mudstone, green, silty, firm, gypsiferous -......-.--

701 Shale, dark-brown, sandy, carbonaceous, firm; weathers rust brown

700 Sandstone, gray, fine-grained, very soft, very friable, limonitic

699 Mudstone, mostly green, some very thin dark-gray to black streaks, silty to sandy, gypsiferous, hard 


\section{PRINCIPAL REFERENCE SECTION FOR THE UPPER PART OF THE ADOBE TOWN MEMBER-Continued}

\section{Washakie Formation (part) -Continued}

Adobe Town Member-Continued

698 Sandstone, gray, fine-grained, fairly well sorted, subangular, partly calcareous and hard, partly soft and friable abundant colored grains; weathers to steep slope; scattered bone fragments

697 Mudstone, medium-gray green, silty, blocky, biotitic, hard; several whole turtles weathering out at the base

696 Mudstone; red at the top, black in the middle, dark green at the bottom; slity, blocky, hard; abundant turtle scutes

Sandstone, gray, fine-grained, fairly well sorted, subangular, firm; and finely interbedded mudstone that is dark green, silty, blocky; hard; abundant turtle bones and scutes

694 Mudstone, dark-green, some dark-gray streaks, silty, blocky, hard

693 Sandstone, gray, fine-grained, fairly well sorted, subangular, firm, friable; thin argillaceous streaks near the center; weathers to smooth, nearly vertical slopes

692 Mudstone, dark-green, thin streaks of dark gray in the lower part, some reddish streaks in the upper part, silty, blocky, hard; and three very thin gray, argillaceous sandstone interbeds

691 Sandstone, gray, very fine grained, fairly well sorted, subangular, micaceous, argillaceous, firm; weathers to nearly vertical slopes; abundant turtle scutes, crocodile bones, scutes, and teeth, and coprolites

Mudstone, green, silty to sandy, blocky, hard; a carbonaceous zone $0.2 \mathrm{ft}$ thick, $1 \mathrm{ft}$ from base

Sandstone, gray, very fine to medium-grained, poorly sorted, subangular, calcareous, firm; abundant colored grains; weathers to small steplike ledges; abundant turtle bones and scutes at the top

688 Mudstone, green, silty, blocky, hard; two very sandy streaks 6 and $12 \mathrm{ft}$ from the top; concretionary zone $3 \mathrm{ft}$ from the base weathers to small, brown, calcareous balls

Sandstone, gray, fine-grained to very coarse grained, poorly sorted, subangular to subrounded, arkosic calcareous in part, firm, crossbedded; abundant colored grains; weathers rust brown; abundant turtle scutes

686 Mudstone, dark-green, dark-gray-green, silty, blocky, hard; some reddish tints in upper $1 \mathrm{ft}$, some interbedded gray argillaceous sandstone; abundant turtle scutes _. -

685 Mudstone, dark-green, orange-red in upper $1 \mathrm{ft}$, silty, blocky, gypsiferous, firm; weathers to rounded, mudcracked slopes 


\section{PRINCIPAL REFERENCE SECTION FOR THE UPPER PART} OF THE ADOBE TOWN MEMBER-Continued

\section{Washakie Formation (part) —Continued}

Adobe Town Member-Continued

684 Sandstone, gray-green, very fine to fine-grained, very argillaceous, very calcareous; contains tan limy inclusions that look like fossil-root impressions-may be a regolith 1

Sandstone, gray, fine- to medium-grained, poorly sorted, subangular, firm, friable; abundant colored grains; weathers to steep slopes

Mudstone, green, silty, blocky, hard; very thin lenses of sandstone, that are gray green, fine to medium grained; abundant colored grains

681 Sandstone, gray-green, fine- to medium-grained, poorly sorted, subangular, firm, friable; abundant colored grains

680 Mudstone, green, silty, blocky, hard _..............

679 Sandstone, gray and greenish-gray, fine- to coarsegrained, poorly sorted, subangular, hard; abundant colored grains; very calcareous at top, crossbedded at basé

678 Mudstone, green, very sandy, argillaceous, firm; very sandy at top; weathers to sloping bench above bed 677

677 Sandstone, gray-green, very fine to medium-grained, fairly well sorted, subangular, tuffaceous, calcareous, firm, crossbedded; weathers to irregular, steep "voodoo" badlands

Sandstone, gray-green, very fine grained, fairly well sorted, very argillaceous to clayey, hard; several $0.2-$ to 0.8-ft-thick lenses of sandstone which are gray, gray green, fine grained, fairly well sorted, subangular, and which contain abundant black and red grains. Unit is calcareous, firm; weathers to nearly vertical badland slopes

Total thickness for the upper part of Adobe Town

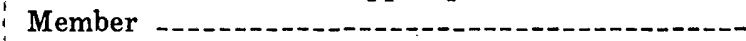

Near base of exposures. Underlying middle part of the Adobe

Town Member described in secs. 29 and 20, T. 13 N., R. 97 W.

\section{ADOBE TOWN MEMBER (TYPE SECTION)} [Exposed on the slopes of a major north-trending dry wash in $N W 1 / 4$ sec. 29 , and W $1 / 2$ sec.
$20, T .13$ N., R. 97 W.]

Washakie Formation (part) :

Adobe Town Member (part) :

Thickness (feet)

675 Mudstone, gray-green, green, silty, blocky, hard -..--.15.5

674 Sandstone, gray-green, fine-grained to very coarse grained, poorly sorted, subangular, crossbedded abundant green feldspar grains; upper $9 \mathrm{ft}$ very argillaceous; a broad channel sandstone 
ADOBE TOWN MEMBER (TYPE SECTION) - Continued

Washakie Formation (part)-Continued

Adobe Town Member-Continued

Thickness

(feet)

673 Mudstone, apple-green, silty, blocky, hard

672 Sandstone, green, fine-grained to very coarse grained, poorly sorted, subangular, lenticular, crossbedided; abundant colored grains

671 Mudstone, green, sandy, blocky, hard; interbedded sandstone that is gray green, fine to coarse grained, poorly sorted, hard

670 Sandstone, gray, fine-grained to very coarse grained, poorly sorted, subangular, firm, friable, lenticular, crossbedded; scattered green clay galls; weathers gray brown; a channel sandstone

669 Mudstone, green, sandy, blocky, firm; interlaminated and finely interbedded sandstone that are gray green, medium grained, subangular, hard; scattered turtle bones

668 Sandstone, gray-green, fine-grained to very coarse grained, poorly sorted, subangular, calcareous, hard; some green clay galls; weathers to thin, persistent, gray-brown bed

667 Sandstone, green, fine- to coarse-grained, poorly sorted, subangular, argillaceous, firm, friable; interbedded mudstone, green, sandy, blocky, hard ..............

666 Sandstone, gray, fine-grained to very coarse grained, poorly sorted, subangular; conglomerate streaks; abundant green feldspar grains; weathers rust brown; a lenticular, crossbedded channel sandstone -........-.-

665 Mudstone, green, silty, blocky, hard; interbedded sandstone that is gray green, fine to coarse grained, poorly sorted, argillaceous, soft _...-...-.

664 Tuff, white, finely bedded; forms a white marker bed in outcrops - . -

663 Sandstone, green, fine-grained to very coarse grained, poorly sorted, very argillaceous; interbedded sandstone that is gray, very coarse grained, calcareous, crossbedded; a broad channel sandstone -................

662 Mudstone, green, silty, blocky, hard, very sandy in part --

661 Sandstone, gray, medium-grained to very coarse grained, poorly sorted, subangular; conglomerate streaks; finely interbedded sandstone that is gray, fine grained, fairly well sorted, very argillaceous, firm. Unit weathers to nearly vertical badland slopes

660 Mudstone, green, silty to sandy, firm, some very thin red streaks; some interbedded sandstone that is gray green, fine grained, very argillaceous, firm. Unit weathers to

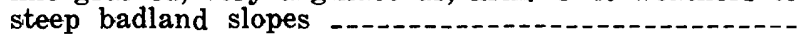

659 Mudstone, gray, silty, gypsiferous, soft; a few thin interbeds of gray, carbonaceous, calcareous, finely bedded, hard siltstone. Unit weathers yellow brown 


\section{ADOBE $;$ TOWN MEMBER (TYPE SECTION)-Continued}

\section{Washakie Formation (part)-Continued}

Adobe Town Member-Continued

658 Mudstone, green, silty to sandy, soft; interbedded sandstone which is gray, fine grained, argillaceous, very soft, and which contains very thin calcareous streaks. Unit weathers to smooth slope

657 Mudstone, brown, gypsiferous, very soft; weathers yellow brown:

656 Mudstone, dark-green, silty, blocky, hard; sandy at base; occasional 0.5- to 1-ft-thick beds of gray, fine-grained to very coarse grained, poorly sorted, calcareous, hard sandstone; some thin interbedded gray, fine-grained, argilláceous, firm sandstone. Unit weathers to smooth slopes:

Sandstone, gray, fine-grained, fairly well sorted, calcareous, hard, limonitic, lenticular, crossbedded; abundant colored grains; weathers rust gray; a channel sandstone

655

654 Mudstone, gray, gray-green, silty, blocky, firm; interbedded gray, fine-grained, poorly sorted, soft to hard, partly $_{i}$ calcareous sandstone. The sandstones form

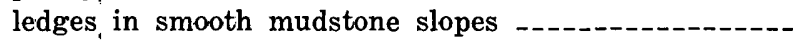

653 Shale, dark-green, fissile, soft, gypsiferous; weathers to yellow-brown, smooth slopes

652 Mudstone, dark-green, silty, soft; in the upper $6 \mathrm{ft}$, interbedded gray-green, fine-grained, very soft, unconsolidated sandstone, small calcite cones $2 \mathrm{ft}$ above base. Unit weathers to smooth slopes

651 Mudstone, gray, silty, blocky, hard; weathers to smooth, gently rounded, yellow-brown badland slopes -......-

650 Mudstone, gray, very silty to sandy, soft; interlaminated to finely interbedded gray, very fine to fine-grained, very soft, unconsolidated sandstone; abundant milky calcite laminae in the upper part; weathers to smooth badland slopes

649 Siltstone, gray, argillaceous, finely bedded, firm; weathers to distinct yellow band in outcrops

648 Sandstone, gray, green, fine-grained, unconsolidated; interbedded gray-green, very silty to very sandy, blocky, hard mudstone

647 Sandstone, brown, fine-grained, fairly well sorted, unconsolidated, very limonitic, gypsiferous (loose pieces of satin spar); weathers to distinct yellow band in outcrops

646 Sandstone, gray, fine-grained, fairly well sorted, calcareous, hard; weathers brown; caps very small dip slope

645 Sandstone, gray, gray-green, fine-grained to very fine grained, poorly sorted, subangular, very soft, argilla- 


\section{ADOBE TOWN MEMBER (TYPE SECTION) - Continued}

\section{Washakie Formation (part) - Continued}

Adobe Town Member-Continued

Thickness (feet)

ceous; dark grains; interbedded gray, silty, blocky, firm mudstone. Unit weathers to smooth slopes

644 Mudstone, apple-green and brick-red, variegated, silty, blocky, firm; a few 0.5- to 1.5-ft-thick beds of gray, fineto coarse-grained, poorly sorted, subangular, finely bedded sandstone that weathers dark brown (rose-red marker bed)

643 Sandstone, gray, fine-grained to very coarse grained, poorly sorted, subangular, firm, friable, silty, partly argillaceous, crossbedded; some distorted wavy bedding planes _........

642 Shale, dark-gray-green, soapy, clayey, blocky, hard -...-

641 Siltstone, gray, argillaceous, carbonaceous, hard; scattered plant fragments; one perfect leaf ..........-.

640 Sandstone, gray, gray-green, mostly fine grained, silty, hard, evenly bedded; very thin interbedded green, very silty, blocky, hard mudstone

639 Mudstone, gray-green, green, very silty, blocky, hard; interlaminated to finely interbedded gray, gray-green, fine- to coarse-grained, poorly sorted, subangular, firm to hard sandstone which contains abundant dark

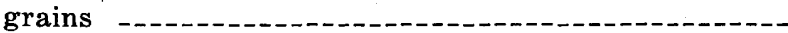

638 Sandstione, gray, fine to very coarse grained, poorly sorted, subangular, crossbedded; abundant colored grains, very argillaceous streaks. In the upper part interbedded gray, very silty, blocky, hard mudstone; a broad flood-plain-type sandstone; one whole turtle weathering out; scattered wood fragments -........

637 Tuff, white, soft to very hard, scattered biotite flakes. A brilliant chalk-white marker bed in outcrops ........-

636 Mudstone, gray, silty, blocky, hard; interbedded sandstone, green, fine- to coarse-grained, poorly sorted, subangular, abundant colored grains, mostly soft and friable, crossbedded, mostly narrow lenses; 1.5-ft-thick bed of chocolate-brown-weathering limy sandstone concretions $15 \mathrm{ft}$ above base; 0.4-ft-thick bed of conglomerate consisting of small, well-rounded, varicolored pebbles of andesite porphyry in a coarsegrained sandstone matrix $15 \mathrm{ft}$ from top; abundant whole turtles weathering out

635 Sandstone, green, fine- to coarse-grained, poorly sorted, subangular, firm, friable, lenticular, crossbedded; abundant colored grains; a channel sandstone; weathers to "voodoo" badlands

634 Mudstone, gray, silty, blocky, hard; in the upper $3 \mathrm{ft}$, some interbedded light-gray, fine-grained, soft, friable sandstone 
ADOBE TOWN MEMBER (TYPE SECTION)-Continued

Washakie Formation (part)-Continued

Adobe Town: Member-Continued

633 Sandstone, dark-green, medium-grained to very coarse grained, poorly sorted, subangular, soft, friable, crossbedded; conglomerate streaks at base; abundant green feldspar grains; weathers to olive-green "voodoo" badlands; abundant fossil wood including many large tree trunks; abundant large mammal bone and tooth fragments including one badly weathered titanothere

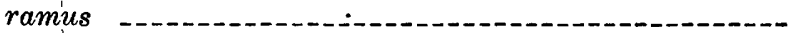

632 Sandstone, gray-green, fine-grained, poorly sorted, very soft, mostly unconsolidated; some small, white, irregularly shaped calcite(?) concretions -..............

631 Mudstone, green, gray-green, silty, fissile to blocky, firm; interbedded gray, fine-grained, poorly sorted, argillaceous, very soft sandstone; an even-bedded, flood-plain sandstone; weathers to nonresistant slopes _........

630 Sandstone, gray, fine-grained, limy, very hard; grades upward into gray, black, oolitic limestone that contains siliceous streaks and pods. Unit weathers dark brown; caps' dipslope -

629 Sandstone, green, fine-grained to very coarse grained, poorly sorted, subangular, crossbedded, very lenticular (mostly narrow channels 5-8 ft thick); abundant colored grains; interbedded gray-green, silty to very sandy, hard mudstone. Scattered poorly preserved fossil leaves in lower $2 \mathrm{ft}$; one fossil tree trunk $41 . \mathrm{ft}$ from base

Total thickness of the type Adobe Town Member

Near base of exposure. Underlying lower part of the Adobe Town Member described in secs. 29 and 20, T. 13 N., R. 98 W.

PRINCIPÁL REFERENCE SECTION FOR THE LOWER PART OF THE ADOBE TOWN MEMBER

[Exposed in NW1/4 sec. 29 and SW1/4 sec. 20, T. 13 N., R. 98 W.]

Washakie Formation (part) :

Adobe Town Member (part) :

628 Sandstone, gray, fine- to medium-grained, poorly sorted, subangular, hematitic, finely bedded; weathers rust .-

627 Shale, medium-gray, clayey, blocky, soft -.........-.

626 Limestone, tan-gray, finely crystalline, hard, dense, very finely bedded, platy; weathers to yellow band in outcrops; appears lacustrine Sandstone, gray, very fine to fine-grained, poorly sorted, subangular, limonitic; abundant colored grains; weathers brown; finely bedded at the top

Mudstone, mostly gray-green, several dark-red beds, silty, blocky, hard; occasional laminae of gray, very fine grained sandstone; weathers to pastel shades of green and red 
PRINCIPAL REFERENCE SECTION FOR THE LOWER PART OF THE ADOBE TOWN MEMBER-Continued

Washakie Formation (part) - Continued

Adobe Town Member (part)-Continued

623 Mudstone, gray, gray-green, silty, blocky, hard; a few thin interbeds of gray-green, fine- to medium-grained, poorly sorted, calcareous, hard, lenticular sandstone; a small channel sandstone

622 Limestone, tan, finely crystalline, very silty, blocky, hard

Thickness (feet)

34.0

618

Mudstone, gray, silty, blocky, firm

620

Tuff, tan, very limy, very silty, hard, finely laminated; weathers brown; caps ridge

Mudstone, green, very sandy, blocky, firm; some interbedded gray, argillaceous sandstone; not well exposed Sandstone, dark-apple-green, fine to very coarse grained, poorly sorted, subangular, soft, friable, crossbedded; a few streaks contain clay galls. Basal $0.3 \mathrm{ft}$ is a black sandstone composed largely of magnetite and heavy minerals (a fossil placer). Abundant very large mammal bones

617 Sandstone, light-gray, very fine to fine-grained, poorly sorted; biotitic, argillaceous, calcareous, finely bedded, appears lacustrine

616 Sandstone, green, fine-grained to very coarse grained, poorly sorted, subangular, calcareous, firm, crossbedded; conglomerate streaks at base; occasional large isolated algal heads as large as $4 \mathrm{ft}$ in diameter. -..--

Mudstone, gray-green, silty, blocky, hard; some very thin interbeds of gray, fine- to medium-grained, firm, friable sandstone

614 Sandstone, gray to apple-green, fine to very coarse grained, poorly sorted, subangular, firm, friable, crossbedded, lenticular; conglomerate streaks at base, abundant colored grains; a channel sandstone; abundant turtle and large mammal bones

Mudstone, gray-green, silty, blocky, hard

-

612 Sandstone, gray-green, fine-to coarse-grained, sorted, subangular, firm, friable, lenticular, crossbedded; a channel sandstone

Mudstone, gray, very sandy, finely bedded, hard poorly sorted, subangular, firm, friable, lenticular, crossbedded; abundant colored grains; a channel sandstone, abundant bone fragments; one humerus about $1 \mathrm{ft}$ long embedded in outcrop

609

Mudstone, gray-green, silty, blocky, hard; very sandy at top; abundant turtle scutes and mammal bone fragments

608

Sandstone, gray-green, fine- to medium-grained, poorly sorted, subangular; abundant colored grains; firm and friable at base; top $1 \mathrm{ft}$ calcareous; weathers brown 
i

PRINCIPAL REFERENCE SECTION FOR THE LOWER PART

OF THE ADOBE TOWN MEMBER-Continued

Washakie Formation (part)-Continued

Adobe Town Member (part) - Continued

at the top; caps small hogback; contains small, poorly preserved Goniobasis sp., Viviparus sp., and Australorbis sp

Mudstone, gray-green, very sandy, very finely bedded, firm

606 Coquinal limestone, gray, sandy, hard; contains Goniobasis sp., very large Gyraulus militaris(?), abundant turtle scutes and fish bones

605 Mudstone, green, sandy, blocky, hard _....................

604 Sandstone, light-gray, fine- to coarse-grained, poorly sorted, subangular, very argillaceous, firm; friable, crossbedded; abundant colored grains; weathers to

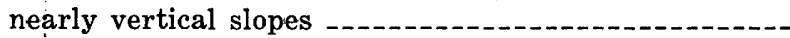

603 Mudstone, dark-gray-green, some red near the center, silty, blocky, hard; two very thin beds of gray-green sandstone; whole turtles weathering out ...........-

602 Limestone, tan-brown, silty, hard; scattered algal colonies as large as $5 \mathrm{ft}$ in diameter, mostly on the upper surface

601 Mudstone, green, silty, blocky, firm

600 Liméstone, tan-gray, very finely crystalline, silty, very hard; weathers light chocolate brown; caps hogback

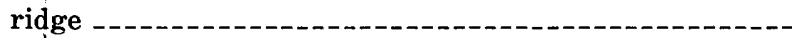

599 Mudstone, green, some horizons of red, sandy, blocky, hard; interbedded gray-green, very fine to mediumgrained, poorly sorted, subangular, argillaceous; hard sandstone that contains abundant colored grains -..--

598 Mudstone, dark-red to orange-red, very sandy, hard; interbedded green, red, argillaceous, hard sandstone; weathers to red band in outcrops; abundant turtle scutes -

597 Mudstone, mostly apple-green, some thin bands of red, very silty, hard; weathers to bright-green band in outcrops; several whole turtles weathering out ..........

596 Mudstone, interbedded pastel shades of maroon and green, very sandy, soft. Some interbedded sandstone which is gray green, very fine to medium-grained, poorly sorted, subangular, very argillaceous, lenticular; colored grains. Unit contains abundant turtle scutes and small mammal bones

595 Sandstone, gray-green, very fine to medium-grained, poorly sorted, subangular, argillaceous, firm. Interbedded mudstone, mostly gray-green, some maroon brown and green, very sandy, firm. Unit contains scattered loose turtle scutes; weathers to pastel colors

594 Liméstone, tan-brown, finely crystalline, silty, very hard; weathers brown 


\section{PRINCIPAL REFERENCE SECTION FOR THE LOWER PART OF THE ADOBE TOWN MEMBER-Continued}

Washakie Formation (part)-Continued

Adobe Town Member (part)-Continued

593 Sandstone, gray-green, very fine to medium-grained, poorly sorted, subangular, soft, friable, argillaceous; abundant colored grains

592 Limestone, medium-gray-brown, finely crystalline, - silty. platy, hard; weathers dark brown; caps ridge .......

591 Sandstone, gray-green, fine to medium-grained, poorly sorted, biotitic, very shaly, soft; occasional thin beds of gray, fissile, firm shale; some thin beds of graygreen, sandy, blocky, firm mudstone

590 Limestone, gray-brown, finely crystalline, silty, very hard, dense; weathers brown; caps ridge

589 Sandstone, gray-green, fine-grained, poorly sorted, shaly; occasional very thin beds of gray-green, very calcareous sandstone

imestone, tan-gray, finely crystalline, silty, hard, dense, finely bedded; weathers yellow brown; appears lacustrine

Mudstone, dark-olive-green, silty, blocky, firm, at base; interbedded with gray, limy, hard siltstone and graygreen, some blue-green, tuffaceous, calcareous, firm sandstone in upper part

Sandstone, light-gray, fine-grained, very tuffaceous, firm, friable; weathers to gray-white band in outcrops -..-

584 Sandstone, gray-green, fine-grained, very soft, unconsolidated, very shaly, nonresistant; thin interbedded lightgray, calcareous, tuffaceous, blocky, hard siltstone andstone, light-gray, fine- to coarse-grained, poorly sorted, very limy; grades upward into tan-gray, silty, very hard limestone; Unit weathers brown; caps hogback ridge

Sandstone, gray-green, fine-grained, subangular, fairly well sorted, biotitic; abundant colored grains. Laterally changes to light-blue-green, very tuffaceous sandstone. A channel sandstone

Siltstone, light-gray, limy, hard, finely bedded. Capped by thin laminae of gray-brown, finely crystalline, platy, hard, dense limestone

Limestone, gray-brown, finely crystalline, hard, dense, platy; finely bedded at the top, very silty the top $1 \mathrm{ft}$; abundant fucoidal markings

Sandstone, brilliant light-blue-green, very tuffaceous, hard; distinct robin's-egg-blue marker bed in outcrops

577 Sandstone, light-gray-green, fine-grained, fairly well sorted, very tuffaceous, calcareous, hard; very large mammal leg bones 
PRINCIPAL REFERENCE SECTION FOR THE LOWER PART

OF ${ }_{\mathrm{i}}$ THE ADOBE TOWN MEMBER-Continued

Washakie Formation (part)-Continued

Adobe Town Member (part)-Continued

Thickness

(feet)

576 Tuff, yellow-gray, blocky, hard; small molds of Australorbis $\mathrm{sp}$

575 Sandstone, light-gray-green, fine-grained, well-sorted, very tuffaceous, calcareous, hard

20.4

Tuff, greenish-gray, silty, very hard

571 Sandstóne, light-gray-green, fine-grained, fairly well sorted, calcareous, firm; abundant colored grains; very

- tuffaceous in bottom $1.5 \mathrm{ft}$

570 Tuff, light-greenish-gray, blocky, hard

569 Sandstone, light-gray-green, fine-grained, fairly well sorted, calcareous, firm; abundant colored grains. Interbedded gray, tuffaceous, calcareous, blocky, very hard siltstone, and green, sandy, blocky, hard mudstone bed (lower brown sandstone)

Total thickness of the lower part of the Adobe Town ,Member

Kinney Rim Member of the Washakie Formation.

\section{KINNEY RIM MEMBER OF THE WASHAKIE FORMATION (TYPE SECTION)}

[The lower part of the type section (beds 515-559) is located on the south slopes of an east-west drainage in the $S 1 / 2$ sec. $16, T$, 14 N., $R$. 99 W., and the upper part of the type section (beds $560-568$ ) is located in the $S W 1 / 4$ sec. $15, T$, 14 N., R. 99 W.1

Washakie Formation (part) :

Kinney Rim Member:

568 Sandstone, light-gray-green, fine-grained, fairly well sorted, calcareous, hard; abundant colored grains -...-

567 Mudstone, green, gray-green, very tuffaceous, silty, blocky, soft. A few 0.5- to 1.5-ft-thick beds of graygreen, fine-grained, fairly well sorted, calcareous, firm sandstone; abundant colored grains ...............

566 Sandstone, gray-green, fine-grained, fairly well sorted, calcareous, firm, lenticular; abundant colored grains; a channel sandstone ...................................

565 Mudstone, apple-green, sandy, firm; occasional 0.5- to 1-ft-thick lenses of greenish-gray, fine-grained, fairly well sorted, calcareous, firm sandstone; unidentified

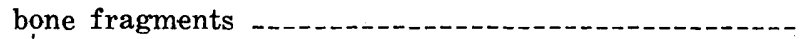

564 Sandstone, greenish-gray, fine-grained, fairly well sorted, subangular, firm; abundant colored grains ..........

563 Mudstone, red, maroon, gray, very sandy, soft; and a few 0.5 - to 1-ft-thick beds of dark-gray-red, some gray, very fine grained, calcareous, firm sandstone 
KINNEY RIM MEMBER OF THE WASHAKIE FORMATION (TYPE SECTION) -Continued

Washakie Formation (part) -Continued

Kinney Rim Member-Continued

562 Sandstone, greenish-gray, fine-grained, fairly well sorted, subangular, firm, crossbedded; abundant colored grains; a channel sandstone -......................

561 Limestone, tan-gray, finely crystalline, silty, very hard, dense; weathers dark brown

560 Mudstone, maroon, dark-orange-red, apple-green, some bands of gray, silty, blocky, soft; occasional 0.5- to 1-ft-thick lenses of dark-gray-red, very fine grained, calcareous, firm sandstone

559 Algal limestone, gray, hard, silty; flattened, gently

rounded platy heads

558 Mudstone, medium-gray, silty, blocky, soft

557 Sandstone, light-gray, very fine grained, micaceous, calcareous, hard

556 Mudstone, gray, gray-green, silty, blocky, soft; occasional thin beds of light-gray, limy, hard siltstone; not well exposed

555 Limestone, light-gray-brown, very finely crystalline, silty, hard, dense, platy

554 Mudstone, dark-green, gray-green, blocky, soft; interbedded light-gray, very fine grained, calcareous, hard sandstone

553 Limestone, light-gray-brown, very silty, hard, platy; weathers brown

552 Sandstone, gray, fine-grained, fairly well sorted, subangular, soft, friable; abundant colored grains; nonresistant

551 Mudstone, dark-green, green-gray, blocky, soft ......-.-

550 Sandstone, light-gray, very fine grained, fairly well sorted, calcareous, hard _.....

549 Mudstone, dark-olive-green, silty, blocky, soft; interbedded light-gray, very fine grained, calcareous, hard sandstone; poorly exposed on soil- and sage-covered dipslope -............

548 Siltstone, light-gray, limy, very tuffaceous, hard ......--

547 Sandstone, light-gray, very fine grained, very calcareous, hard; interbedded olive-green, silty, blocky, firm mudstone, and light-gray, very limy, very hard siltstone;

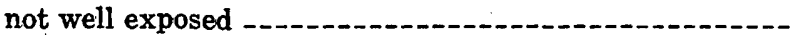

546 Mudstone, dark-olive-green, silty, blocky, firm -...-...--

545 Limestone, tan, finely crystalline, hard, dense ...........

544 Sandstone, gray, very fine grained, calcareous, hard ...-

543 Mudstone, gray-green, silty, blocky, soft; thin interbedded gray, very fine grained, calcareous, hard sandstone -._-_-

542 Sandstone, gray, fine- to coarse-grained, poorly sorted, subangular, soft to hard, crossbedded; calcareous 


\section{KINNEY RIM MEMBER OF THE WASHAKIE FORMATION} (TYPE SECTION) - Continued

\section{Washakie Formation (part)-Continued}

Kinney Rim Member-Continued

streaks; scattered clay-gall conglomerate lenses, non-

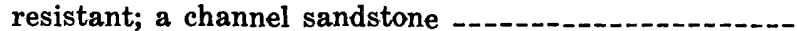

541 Sandstone, gray, very fine to fine-grained, calcareous, firm; occasional thin interbedded olive-green, sandy, blocky, firm mudstone -.....

539 Shale, gray-brown, flaky, firm; appears lacustrine .....

538 Sandstone, gray, very fine to medium-grained, poorly sorted, subangular, micaceous; colored grains; interbedded olive-green, very sandy mudstone _..........-

537 Sandstone, gray, very fine to medium-grained, poorly sorted, subangular, micaceous, crossbedded; colored grains; scattered clay-gall conglomerate streaks; weathers to rust-brown ledge

536 Mudstone, dark-olive-green, silty, blocky, firm -......-.

535 Limestone, tan-gray, finely crystalline, very sandy, very hard

534 Mudstone, dark-olive-green, silty, blocky, firm -...--

533 Sandstone, gray, fine- to medium-grained, poorly sorted, subangular, firm, friable, crossbedded; conglomerate streaks of gray siltstone and mudstone clay galls near base; a channel sandstone; weathers to rust-brown ledge

Mudstone, dark-olive-green-gray, silty, blocky, firm; occasional thin lenses of light-gray, very fine grained, calcareous, hard sandstone

Limestone, brown, finely crystalline, sandy, hard, dense; weathers to white band in outcrops

530 Mudstone, dark-olive-green-gray, silty, blocky, firm -...--

529 Limestone, brown, finely crystalline, sandy, hard, dense -

528 Mudstone, dark-olive-green-gray, silty, blocky, firm -...-

527 Covered by soil and sagebrush

526 Sandstone, light-gray, very fine to fine-grained, poorly sorted, subangular, calcareous, hard; colored grains; weathers to long dipslope -

525 Limestone, tan-gray, brown, finely crystalline, silty, hard dense

Mudstone, dark-olive-green-gray, silty to sandy, blocky, firm:

Limestone, tan-gray, very finely crystalline, hard, dense, silty; weathers to irregularly shaped, flattened plates

Mudstone, dark-olive-green, some mottled black, silty to sandy, blocky, firm; clayey at top

Limestone, tan-gray, very finely crystalline, silty, hard, dense (almost a sandstone); finely interlaminated to inter- 
KINNEY RIM MEMBER OF THE WASHAKIE FORMATION

(TYPE SECTION) - Continued

Washakie Formation (part) -Continued

Kinney Rim Member-Continued

bedded sandstone, gray, very fine grained, calcareous, hard -......-.....

519 Limestone, tan, very finely crystalline, silty, hard, dense, platy; appears lacustrine

518 Mudstone, dark-olive-green-gray, silty to sandy, blocky, firm; and occasional 1- to 1.5-ft-thick beds of gray, very fine grained, silty, calcareous, firm sandstone -..-

517 Sandstone, gray, very fine to fine-grained, fairly well sorted, subangular, calcareous, firm to soft; nonresist-

$$
\text { ant }
$$

516 Mudstone, gray, gray-green, silty, blocky, firm

515 Tuff, light-gray, very limy (almost tuffaceous limestone), silty, hard, dense, platy; the white ridge marker bed --

Total thickness of Kinney Rim Member of the Washakie Formation

Green River Formation, Laney Shale Member.

The section for 900 feet below bed 515 consists mostly of tuffaceous sandstone and siltstone and some thin interbedded green mudstone and oil shale that compose the upper part of the Laney Shale Member of the Green River Formation along Kinney Rim.

\section{REFERENCES CITED}

Bradley, W. H., 1945, Geology of the Washakie Basin, Sweetwater and Carbon Counties, Wyoming, and Moffat County, Colorado, 1945: U.S. Geol. Survey Oil and Gas Inv. Prelim. Map 32.

1964, Geology of Green River Formation and associated Eocene rocks in southwestern Wyoming and adjacent parts of Colorado and Utah: U.S. Geol. Survey Prof. Paper 496-A, p. A54-A86.

Cope, E. D., 1873, The monster of Mammoth Buttes [Loxolophodon cornutus Cope]: Pennsylvania Monthly, v. 4, p. 521-534.

Gazin, C. L., 1959, Paleontological exploration and dating of the early Tertiary deposits in basins adjacent to the Uinta Mountains [Utah, Wyo.-Colo.], in Intermtn. Assoc. Petroleum Geologists Guidebook 10th Ann. Field Conf., Wasatch and Uinta Mountains: p. 131-138.

Granger, Walter, 1909, Faunal horizons of the Washakie formation of southern Wyoming: Am. Mus. Nat. History Bull., v. 26, p. 13-23.

Hayden, F. V., 1869, Preliminary field report [3d ann.] of the U.S. Geological Survey of Colorado and New Mexico: Washington, $155 \mathrm{p}$.

-1871, Preliminary report [4th ann.] of the U.S. Geological Survey of Wyoming and portions of contiguous Territories: Washington, 511 p.

1877, Notes on some artesian borings along the line of the Union Pacific Railroad in Wyoming Territory: U.S. Geol. Geog. Survey Terr., v. 3, no. 1, p. 181-185.

Johannsen, Albert, 1914, Petrographic analysis of the Bridger, Washakie, and other Eocene formations of the Rocky Mountains: Am. Mus. Nat. History Bull., v. 33, p. 209-222. 
King, Clarence, 1876, Annual report upon the geological exploration of the fortieth parallel from the Sierra Nevada to the eastern slope of the Rocky Mountains: U.S. Geol. Explor. 40th Parallel, 6 p.

1877, Descriptive geology: U.S. Geol. Explor. 40th Parallel, v. 2, p. 202-277.

1878, Systematic geology: U.S. Geol. Explor. 40th Parallel, v. 1, 803 p.

Matthew, W. D., 1909, The Carnivora and Insectivora of the Bridger Basin, middle Eocene: Am. Mus. Nat. History Mem., v. 9, pt. 6, p. 289-567.

McGrew, P. O., 1951, Tertiary stratigraphy and paleontology of southcentral Wyoming, in Wyoming Geol. Assoc. Guidebook 6th Ann. Field Conf., 1951, south-central Wyoming: p. 54-57.

McGrew, P. O., and Sullivan, Raymond, 1970, The stratigraphy and paleontology of Bridger A: Wyoming Univ. Contr. Geology, v. 9, no. 2, p. $66-85$.

McMaster, J. B., 1881, Stratigraphical report upon the Bridger beds in the Washakie Basin, Wyoming: E. M. Mus. Geology and Archaeology of the College of New Jersey Contr., v. 1, no. 1, p. 45-54.

Marsh, O. C., 1885, Dinocerata, a monograph of an extinct order of gigantic mammals: U.S. Geol. Survey Mon. 10, 243 p.

Morris, W. J., 1954, An Eocene fauna from the Cathedral Bluffs tongue of the Washakie Basin, Wyoming: Jour. Paleontology, v. 28, no. 1, p. 195-203.

Osborn, H. F., 1881, A memoir upon Loxolophodon and Uintatherium: E. M. Mus. Geology and Archaeology of the College of New Jersey Contr., v. 1, no. 1, p. 1-44.

1929, The titanotheres of ancient Wyoming, Dakota, and Nebraska: U.S. Geol. Survey Mon. 55, v. 1, p. 1-701.

Roehler, H. W., 1969, Stratigraphy and oil-shale deposits of Eocene rocks in the Washakie Basin, Wyoming, in Wyoming Geol. Assoc. Guidebook 21st Field Conf. Tertiary rocks of Wyoming: p. 197-206.

1970, Nonopaque heavy minerals from sandstone of Eocene age in the Washakie Basin, Wyoming, in Geological Survey research 1970, U.S. Geol. Survey Prof. Paper 700-D, p. D181-D187.

Schultz, A. R., 1920, Oil possibilities in and around Baxter Basin, in the Rock Springs uplift, Sweetwater County, Wyoming: U.S. Geol. Survey Bull. 702, $107 \mathrm{p}$.

Scott, W. B., 1890, The Mammalia of the Uinta formation: Am. Philos. Soc. Trans., v. 16, p. 461-572.

Simpson, G. G., 1933, Glossary and correlation charts of North American Tertiary mammal-bearing formations: Am. Mus. Nat. History Bull., v. 67, p. $79-121$.

Sinclair, W. J., 1909, The Washakie, a volcanic ash formation: Am. Mus. Nat. History Bull., v. 26, p. 25-27.

Wheeler, W. H., 1961, Revision of the Uintatheres: Yale Univ. Peabody Mus. Nat. History Bull. 14, 93 p.

Wood, H. E., 2d, 1934, Revision of the Hyrachyidae: Am. Mus. Nat. History Bull., v. 67, art. 5, p. 181-295.

Wood, H. E., 2d, chm., 1941, Nomenclature and correlation of the North American continental Tertiary: Geol. Soc. America Bull., v. 52, no. 1, p. $1-48$. 
Roehler-STRATIGRAPHY, WASHAKIE FORMATION, WASHAKIE BASIN, WYOMING-Geological Survey Bulletin 1369 